\title{
Key parameters of volcanic tuffs used as building stone: a statistical approach
}

\author{
Christopher Pötzl ${ }^{1}$ (1) $\cdot$ Siegfried Siegesmund ${ }^{1} \cdot$ Rubén López-Doncel $^{2} \cdot$ Reiner Dohrmann $^{3,4}$ (i)
}

Received: 16 July 2021 / Accepted: 10 November 2021 / Published online: 8 December 2021

(c) The Author(s) 2021

\begin{abstract}
Volcanic tuffs naturally show a strong heterogeneity in their petrography and petrophysical properties. The arrangement of the components in tuffs can create a very wide spectrum of porosities and fabrics, which in turn can lead to a highly differential weathering behavior. Considerable amounts of clay minerals and zeolites are common and can contribute to a high sensitivity to expansional processes and salt crystallization. Understanding the influence of the rock properties on material behavior and durability can help to make predictions on future material behavior and evaluate the suitability of the material for construction purposes. This study presents the petrographic and petrophysical data of 15 selected tuffs and 513 tuffs from the literature used as building stones. Regression analysis show if parameters are comparable and if key parameters can be identified. Key parameters can potentially be used for the estimation of the material behavior, without the use of expensive analytics or weathering simulations.
\end{abstract}

Keywords Volcanic tuff $\cdot$ Key parameters $\cdot$ Statistics $\cdot$ Prediction of material behavior

\section{Introduction}

Availability, good workability, excellent aesthetic variability, as well as favorable insulation properties were always convincing reasons for the utilization of volcanic tuffs in the architectural and artistic application. Through all cultures and epochs worldwide tuffs have been used as construction material for the creation of buildings, artworks and sculptures (Fig. 1). As popular as the material is, however,

This article is part of a Topical Collection in Environmental Earth Sciences on "Building Stones and Geomaterials through History and Environments-from Quarry to Heritage. Insights of the Conditioning Factors", guest edited by Siegfried Siegesmund, Luís Manuel Oliveira Sousa, and Rubén Alfonso López-Doncel.

Christopher Pötzl

christopher.poetzl@gmx.de

1 Geoscience Centre of the University Goettingen, Goettingen, Germany

2 Geological Institute of the Autonomous University of San Luis Potosí, San Luis Potosí, Mexico

3 Federal Institute for Geosciences and Natural Resources (BGR), Hanover, Germany

4 State Authority of Mining, Energy and Geology (LEBG), Hanover, Germany it is often very sensitive to weathering, and the reasons for their fast deterioration are manifold and have been the subject of many studies (e.g., Auras et al. 2000; Çelik and Sert 2020; Egloffstein 1998; Fitzner and Basten 1994; Pötzl et al. 2018b; Ünal 2011; van Hees et al. 2003; Wedekind et al. 2013; Yu and Oguchi 2010). Some of the main culprits are the characteristic high porosity, a strong affinity for water absorption, low strength values and a frequent abundance in swelling clays (see discussions in López-Doncel et al. 2016; Pötzl et al. 2018b).

The group of rocks that are under investigation here, although they are summarized under the term "tuff", are truly different in every conceivable way. The International Union of Geological Sciences (IUGS) defines tuffs as volcaniclastic rocks, that consist of at least $75 \%$ volcanic ash $<2 \mathrm{~mm}$ (Le Maitre et al. 2002). However, commonly accepted the term tuff is used as a collective term, to describe any volcaniclastic rock with $>75 \%$ pyroclasts of any size. The term pyroclast refers to any fragment generated directly as a result of volcanic activity and includes individual crystals, glass and rock fragments. Volcanic tuff is an extrusive igneous rock formed by the consolidation and lithification of volcanic products, which have been ejected by an explosive volcanic eruption. Tuff deposits can reach thicknesses of hundreds of meters and total eruptive volumes 

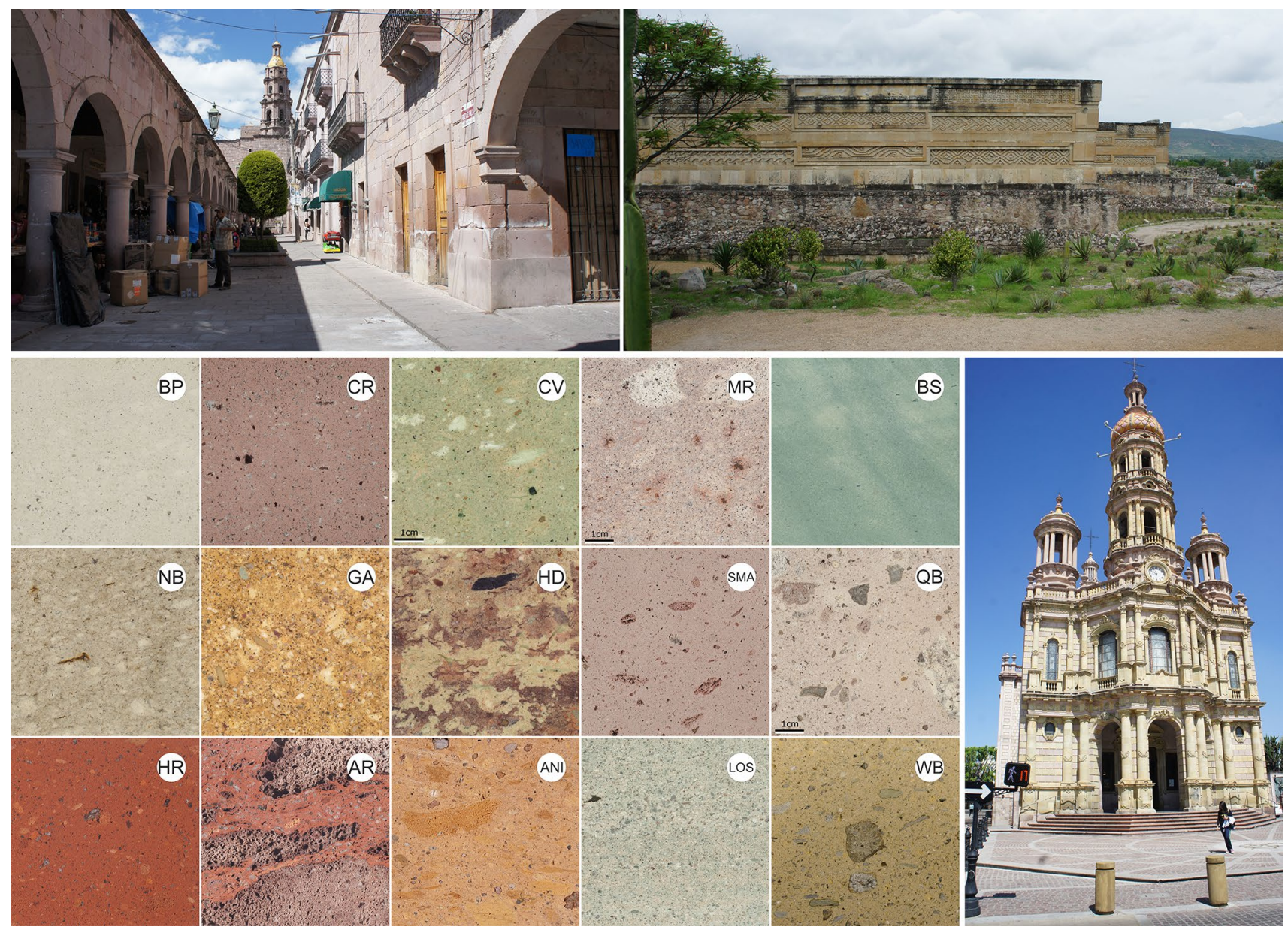

Fig. 1 Volcanic tuffs in building heritage. Top left: the city center of San Miguel el Alto, Mexico; top right: the second century Mitla Pyramids, Mexico; bottom right: the twentieth century Temple of Saint
Anthony of Padua in Aguascalientes, Mexico; bottom left: macro photographs of the 15 tuffs investigated in this study of many cubic kilometers. They may be formed by a single eruptive event or from successive surges from a single eruption or eruptions that were separated by longer periods of time.

Volcanic tuffs can have a wide variety of textures, depending on the type and amount of pyroclastic content or their degree of welding. They frequently show fragmented texture: characteristic texture of pyroclastic rocks with a mixture of rock fragments, crystals and glass; eutaxitic or vitroclastic texture: formed by collapsed pumice and glass fragments called fiammes; axiolitic texture: formed by radial fibers emerging through a core formed by devitrification; or laminar texture: if formed by the fall of volcanic ash at different intervals or time-lapses. If the ejected volcanic products were hot enough $\left(>600{ }^{\circ} \mathrm{C}\right)$, they were welded together upon impact or compaction. The rock formed from this extraordinary hot ejecta is known as a welded tuff or ignimbrite (in the case of ash flows).
Tuffs can be classified according to the size of their pyroclastic fragments (Fisher 1966) or to the type of pyroclastic fragments (Schmid 1981). Fragment sizes range from ash $(<2 \mathrm{~mm})$ and lapilli $(64-2 \mathrm{~mm})$ to blocks and bombs (>64 mm). The main fragment types are of either crystal, vitric or lithic nature. The total alkali versus silica (TAS) classification system after Le Bas et al. (1986) is used for the geochemical classification of pyroclastic rocks, since the modal content of tuffs cannot always be determined accurately with the QAPF diagram (Le Maitre et al. 1989; Streckeisen 1978), due to the often cryptocrystalline and glassy texture of the groundmass. Usually, volcanic tuff is composed of a high percentage of silica $\left(\mathrm{SiO}_{2}\right)$ and a great amount of the matrix consists of volcanic glass. The formation by explosive eruptions means association with acid magmas; hence, minerals like quartz, plagioclase, potassium feldspars and mica are often found in tuffs. However, it is not uncommon to find volcanic tuffs of intermediate to basic composition. 
The main components of tuffs are usually rock fragments, ash particles and scoria, that were ejected and deposited by violent volcanic eruptions and subsequently compacted and welded together to different degrees. Many contributing factors open the possibility to almost limitless heterogeneity. Significant contributing factors are the initial composition and cooling rate of the magma, the ratio of the draggedalong and incorporated components, degassing processes, different depositional and reworking environments, as well as subsequent alteration processes that may form new minerals with high impact on the strength and durability. The mineralogical and fabric heterogeneity of tuffs make it very difficult to determine reliable durability parameters and predict material behavior, which in turn is crucial for their quality assessment. Therefore, the evaluation for the construction suitability of tuffs is always associated with comprehensive and cost-intensive material characterization and testing.

For any type of geotechnical engineering purpose, like construction and mining, typically the rock strength is used as one of the basic parameters to classify the quality of the material and its suitability for construction purposes (Benavente et al. 2004; Siegesmund and Dürrast 2011). Together with the pore space properties, it can be used to estimate the stone's durability, which is defined as the ability to maintain essential and distinctive characteristics of the stone over the course of its lifespan. The standardized assessment of strength parameters is often linked to a timeand cost-intensive destructive testing, which requires a formidable amount of sample material. Over the past years, in a growing amount of studies the authors were able to estimate the material behavior of dimension stones based on petrophysical data. Many authors were able to identify interrelationships between different rock properties and their particular influence on their weathering behavior (e.g., Benavente et al. 2004; Binal 2009; Bodnár et al. 2011; Davarpanah et al. 2020; Germinario et al. 2017; Gioncada et al. 2011; González et al. 2019; İnce et al. 2019; Jamshidi et al. 2018; López-Doncel et al. 2016; Morales Demarco et al. 2007; Mosch and Siegesmund 2007; Pötzl et al. 2018b; Sengun et al. 2014; Siegesmund et al. 2000; Snethlage and Wendler 1997; Sousa 2014; Stück et al. 2013; Teymen 2018; Török et al. 2007; Wedekind et al. 2013; Xue et al. 2020). Although these studies led to a better understanding and prediction of the material behavior, the findings are often limited to certain types of rock and only applicable for individual cases.

Another observation is the frequent use of relatively small datasets and neglect of a deep petrographic investigation, which do not allow for general statements about the wide ranges of rock types and their parameters. However, some authors like Mosch and Siegesmund (2007) or Stück et al. (2013) conducted studies on hundreds of data points from the literature and were able to establish criteria and systems to better qualify plutonic rocks, limestones, and sandstones for construction suitability and predict their weathering behavior. Stück et al. (2013) were even able to create a quality catalogue for different types of sandstone, based on their textural and compositional maturity.

Various studies on volcanic tuffs present a considerable amount of thoroughly treated data (e.g., Auras and Steindlberger 2005; Bozdağ and Ince 2018; Çelik and Çobanoğlu 2019; İnce et al. 2019; Korkanç and Solak 2016; LópezDoncel et al. 2016; Steindlberger 2004; Teymen 2018; Török et al. 2007; Wedekind et al. 2013). To the authors' knowledge, however, no such comprehensive study for tuffs exists, that integrates petrographic, technical and durability parameters with a larger set of data points. Besides the fact that studies on volcanic tuffs as dimensional stones are significantly underrepresented in the literature when compared to other magmatic building stones, sandstones, or limestones for example (Wedekind 2016), the comparability of tuffs often turns out to be a challenging task because of their great heterogeneity even when looking at small-scale comparison of material from the same outcrop (Germinario and Török 2019; Siedel 2017).

In this study, the petrophysical data of up to 513 tuffs from the literature are used to analyze the distribution and limits of single rock properties and to identify interrelationships between them, with the goal of identifying key parameters for the estimation of their weathering behavior. In addition, 15 selected tuffs were investigated in more detail, to extrapolate to the very comprehensive, but less detailed dataset from the literature and achieve larger representability.

\section{Materials and methods}

A total of 15 volcanic tuffs from Armenia, Germany, and Mexico, which are frequently used as building stones (Table 1), were investigated in terms of their petrographical and petrophysical properties, as well as their weathering characteristics. This study includes a brief summary of their petrography. Please find more detailed descriptions in Pötzl (2020). The subsequent section will then present the petrophysical data of these tuffs. To obtain a more comprehensive dataset, the data of the detailed study were complemented with additional petrophysical data from 123 literature sources, representing a total of 513 tuffs from 21 countries. The references are listed in Table 6 in the appendix.

\section{Statistical methodology}

Univariate and bivariate statistical analyses were applied on up to 528 tuffs from the database with the open software 'RStudio'. Box-and-whisker plots (boxplots) were used to display the distribution of single rock properties (univariate method). They essentially consist of two parts: a box and 
Table 1 Overview of the 15 investigated tuffs

\begin{tabular}{lllllll}
\hline Sample & ID & Origin & Age & $\begin{array}{l}\text { Classification Le } \\
\text { Bas et al. (1986) }\end{array}$ & $\begin{array}{l}\text { Classification } \\
\text { Schmid (1981) }\end{array}$ & $\begin{array}{l}\text { Classification } \\
\text { Fisher (1966) }\end{array}$ \\
\hline Blanca Pachuca & BP & Mexico & Pliocene & Rhyolite & Crystal & Ash tuff \\
Cantera Rosa & CR & Mexico & Oligocene & Rhyolite & Crystal & Ash-lapilli tuff \\
Cantera Verde & CV & Mexico & Miocene & Rhyolite & Crystal & Ash tuff \\
Mitla Rosa & MR & Mexico & Miocene & Rhyolite & Crystal & Ash-lapilli tuff \\
Blue Sevan & BS & Armenia & Cretaceous & Rhyolite & Crystal & Ash tuff \\
Noyemberyan & NB & Armenia & Cretaceous & Rhyolite & Crystal & Ash tuff \\
Golden Armenia & GA & Armenia & Cretaceous & Rhyolite & Crystal & Lapilli tuff \\
Hilbersdorf & HD & Germany & Permian & Rhyolite & Crystal & Lapilli tuff \\
San Miguel el Alto & SMA & Mexico & Paleogene & Rhyolite & Vitric & Lapilli tuff \\
Queretaro Blanco & QB & Mexico & Pliocene & Rhyolite & Vitric & Lapilli tuff \\
Hoktemberyan Red & HR & Armenia & Pleistocene & Trachyte & Vitric & Lapilli tuff \\
Artik Rosa & AR & Armenia & Pleistocene & Trachyte & Vitric & Tuff breccia \\
Ani Peach & ANI & Armenia & Quaternary & Rhyolite & Vitric & Lapilli tuff \\
Loseros & LOS & Mexico & Oligocene & Rhyolite & Lithic & Ash tuff \\
Weibern & WB & Germany & Pleistocene & Trachyte-Phonolite & Lithic & Lapilli tuff \\
\hline
\end{tabular}

Classifications according to Fig. 3 a set of whiskers. The box displays the interquartile range (IQR) in which $50 \%$ of the values are present, limited by the median of the lower (25\% quartile) and upper (75\% quartile) half of the dataset. A horizontal line inside the box represents the median of the whole dataset and its position allows for an estimation of the skewness of the data distribution. The whiskers are drawn until the minimum and maximum values. Their length is limited to 1.5 times of the IQR (Tukey 1977) and any lower or higher values are plotted as outliers. The data of the 15 representative tuffs of this study is included into the big dataset. To visualize, however, the representativity of the selected tuffs, the range of their single rock properties is presented as a red line, next to the boxplots.

Regression analyses investigate the relationship of two properties and reveal if the parameters are comparable (bivariate method). The data are presented in point diagrams with the correlation coefficient $r$ expressing the relation between two parameters (Spearman rank correlation coefficient). The correlation coefficient $r$ varies between 1 and -1 , whereby values close to 1 or -1 describe a significant correlation between the parameters and values close to 0 describe a lack of relationship. Under the assumption that the rock properties show normal distribution, confidence regions with $80 \%$ probability range are displayed as ellipses within the regression analyses.

\section{Difficulties in data comparability}

The compilation of a summarizing global overview bears certain risks that can potentially lead to an increased scattering of data. First of all, a global compilation of a high number of data points can per se lead to a wider scattering as a limited dataset (Büttgenbach 1990). The determination of technical parameters is usually based on country- or societyspecific norms and standards, like the American Society for Testing and Materials (ASTM), German Institute for Standardization (DIN), Turkish Standards Institution (TSE), or International Society for Rock Mechanics (ISMR), to just name a few. Although, in the past decades, institutions like the European Committee for Standardization (CEN) or the International Organization for Standardization (ISO) promoted an international alignment of norms and standards, the laboratory testing procedures in many countries are still conducted following deviant standards. When comparing results from different international standards Mosch and Siegesmund (2007) point out the striking example of Peschel (1983), who observed a 10-20\% decreased uniaxial compressive strength (UCS) of test specimens with a ratio of $h / d>2$, compared to specimens with a ratio of $h / d=1$ (following DIN EN 1926).

Further substantial influences on the results can be the different shape of the test specimens (e.g., cylinders react different to stress than cubes), the particular laboratory conditions (e.g., increased relative humidity), experimental procedure (e.g., different strain rates), and in the end human failure during testing, evaluation and documentation. It is also important to mention that tuffs, due to their depositional conditions and frequent directional fabric, often show strong directional dependence, as demonstrated by several authors (e.g., Colella et al. 2017; López-Doncel et al. 2013; Martin III et al. 1992; Pötzl et al. 2018a; Stück et al. 2008; Weiss et al. 2004), which, however, is not considered in many studies. To maintain a large and representative dataset, the most 
commonly published mean values of the technical parameters were therefore used for the statistical analyses. However, like in the previous mentioned studies, the results of the additional 15 selected tuffs, which were investigated in more detail, illustrate that the mean values are not always representative and many technical parameters can differ by a multiple when determined parallel or perpendicular to the bedding plane. Please note that for most of the 513 tuffs from the literature, not all of the technical parameters that were obtained in the present study were determined in the respective studies. Therefore, the comparability of various parameters is limited.

\section{Analyses of the petrography and petrophysical parameters}

The petrographic analyses were performed on oriented thin sections under a polarisation microscope, as well as on a scanning electron microscope (SEM) with adjacent energydispersive X-ray spectroscopy (EDX) for mineral identification. X-ray diffraction (XRD) of whole rock samples and oriented slides of the clay fraction $<2 \mu \mathrm{m}$ along with $\mathrm{X}$-ray fluorescence (XRF) were used for the mineralogical and geochemical characterization. They were supported by analysis of the cation exchange capacity (CEC) analyses determined after the copper (II) triethylenetetramine method of Dohrmann and Kaufhold (2009), modified from Meier and Kahr (1999).

The effective porosity, bulk, and matrix densities were determined by hydrostatic weighing on sample cubes of $65 \mathrm{~mm}$ edge length after DIN 772-4. The quotient of unforced (atmospheric conditions) and forced (vacuum) water saturation was used to determine the saturation degree $S$ (Hirschwald 1912). The pore radii distribution of the samples was determined on sample fragments after DIN 66133 by mercury intrusion porosimetry (MIP). The specific surface area (SSA) was determined by means of $\mathrm{N}_{2}$ gas adsorption based on the Brunauer-Emmett-Teller theory (BET).

The capillary water uptake ( $w$ value) was determined according to DIN EN ISO 15148 on sample cubes of $65 \mathrm{~mm}$ edge length in a closed cabinet while weighing over time. On sample discs with a diameter of $40 \mathrm{~mm}$ and a thickness of $10 \mathrm{~mm}$, the water vapor diffusion resistance ( $\mu$ value) was measured using the wet-cup method according to DIN EN ISO 12572. The hygroscopic water sorption was measured according to DIN EN ISO 12571 in a climate chamber at $20{ }^{\circ} \mathrm{C}$ temperature and relative humidities (RH) between 25 and $95 \%$. Due to time constraints, the relative humidity was increased by $10 \%$ every $48 \mathrm{~h}$, while determining the weight difference before every humidity increase.

The ultrasonic $\mathrm{P}$-wave velocity was determined via direct transmission of the ultrasonic travel time through cylindrical specimens (50 mm length, $15 \mathrm{~mm}$ diameter) according to DIN 14579, with a frequency of $350 \mathrm{kHz}$. It was also used as a non-destructive tool to obtain the dynamic Young's modulus $\left(E_{\mathrm{dyn}}\right)$, which is proportional to the rock strength (Siegesmund and Dürrast 2011).

By means of the Brazil test (or indirect tensile strength test) according to DIN 22024, the tensile strength (TS) was measured on disc-shaped specimens of $20 \mathrm{~mm}$ length and $40 \mathrm{~mm}$ diameter under dry and water saturated conditions. A universal press from Walter and Bai applied a progressive compressional load (increasing $30 \mathrm{~N} / \mathrm{s}$ ). The uniaxial compressive strength (UCS) under dry and water saturated conditions was determined according to DIN EN 1926 on cylindrical samples of $50 \mathrm{~mm}$ length and diameter with a strain rate of $1000 \mathrm{~N} / \mathrm{s}$ until failure. To identify anisotropic behavior of the tuffs, both TS and UCS were determined parallel ( $X$ direction) and perpendicular ( $Z$ direction) to the bedding plane, on a minimum of six specimens per direction. The static Young's modulus $\left(E_{\text {stat }}\right)$ was derived from the linear portion of the stress-strain curve of the uniaxial compressive strength.

The hydric expansion was measured on cylindrical samples of $50 \mathrm{~mm}$ length and $15 \mathrm{~mm}$ diameter under conditions of complete immersion in demineralized water, following DIN 13009. A displacement transducer with a resolution of $0.1 \mu \mathrm{m}$ measured the linear expansion as a function of time. The salt weathering resistance was determined by a cyclic salt weathering test, inspired by the standard DIN EN 12370 on sample cubes of $65 \mathrm{~mm}$ edge length. For one cycle of the test, the dry cubes were put in a $10 \%$ solution of sodium sulfate $\left(\mathrm{Na}_{2} \mathrm{SO}_{4}\right)$ for $4 \mathrm{~h}$. The samples were afterwards dried in an oven $\left(60^{\circ} \mathrm{C}\right)$ for $24 \mathrm{~h}$ and subsequently weighed. This process was repeated until a minimum weight loss of at least $30 \%$ was achieved.

\section{Results and discussion}

\section{Petrography and mineralogy}

Geochemically, most of the 15 investigated volcanic tuffs are acid rhyolites or trachytes. Only the Weibern tuff (WB) shows an intermediate trachytic to phonolitic composition, with low $\mathrm{SiO}_{2}(59.1 \mathrm{wt} \%)$ and high $\mathrm{Na}_{2} \mathrm{O}$ and $\mathrm{K}_{2} \mathrm{O}$ content (>10 wt\%) (Fig. 2). After the classification scheme of Schmid (1981), BP, CR, CV, MR, BS, NB, GA and HD can be defined as crystal tuffs. Note that all crystal tuffs are clearly acid with $\mathrm{SiO}_{2}$ content $>70 \%$. SMA, QB, HR, AR and ANI can be classified as vitric tuffs and LOS and WB as lithic tuffs (Table 1; Fig. 3). Regarding the size of pyroclastic fragments (Fisher 1966), the investigated tuffs are mainly defined as ash tuffs and lapilli tuffs. Artik Rosa (AR) is the only representative of tuff breccia. The crystal-rich tuffs are mostly ash tuffs and lapilli tuffs with high ash content. Only 


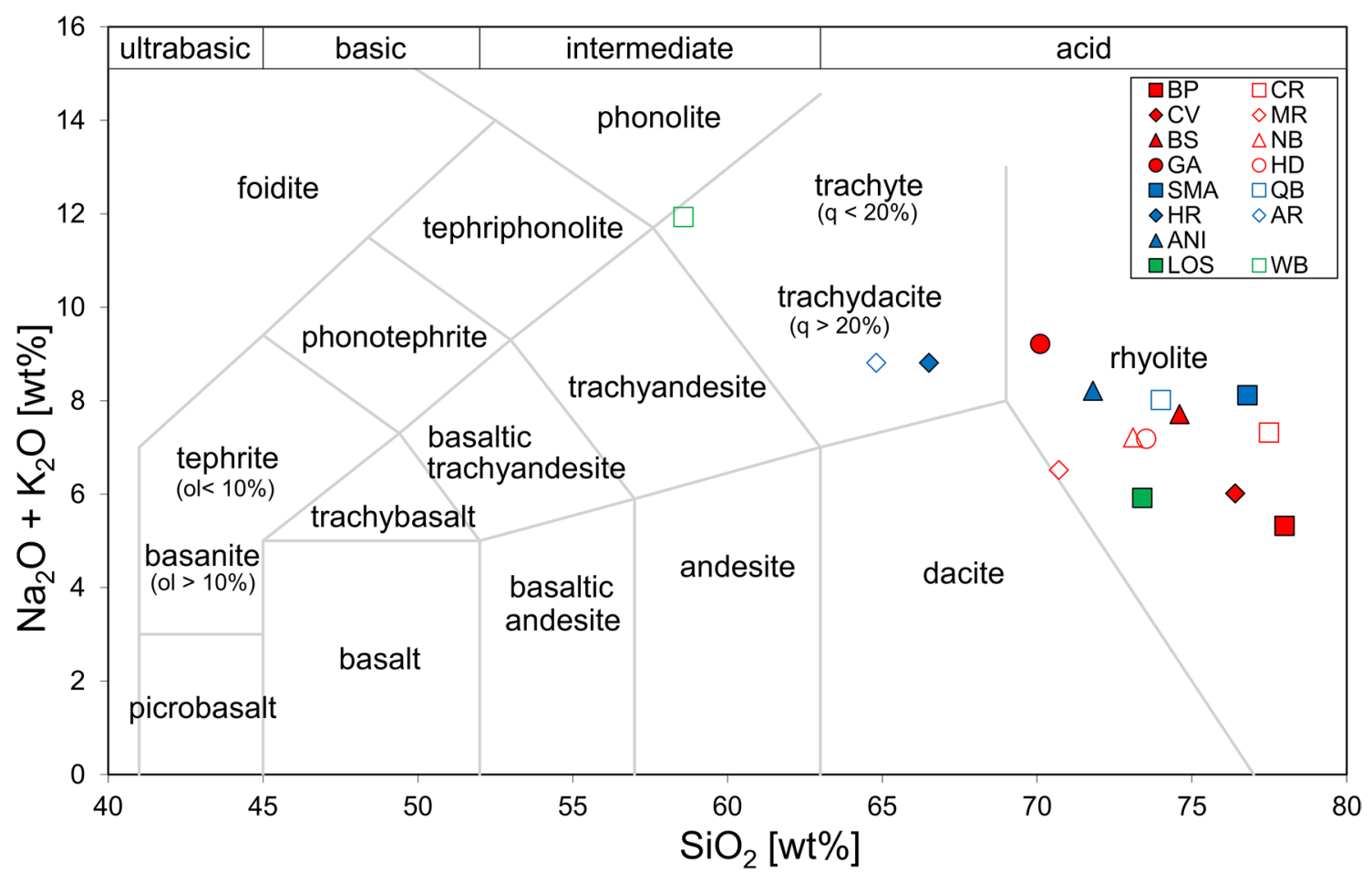

Fig. 2 Geochemical classification according to the total alkali-silica diagram after Le Bas et al. (1986). The tuffs are colored after their main pyroclastic content: red $=$ crystal tuff, blue $=$ vitric tuff, green $=$ lithic tuff

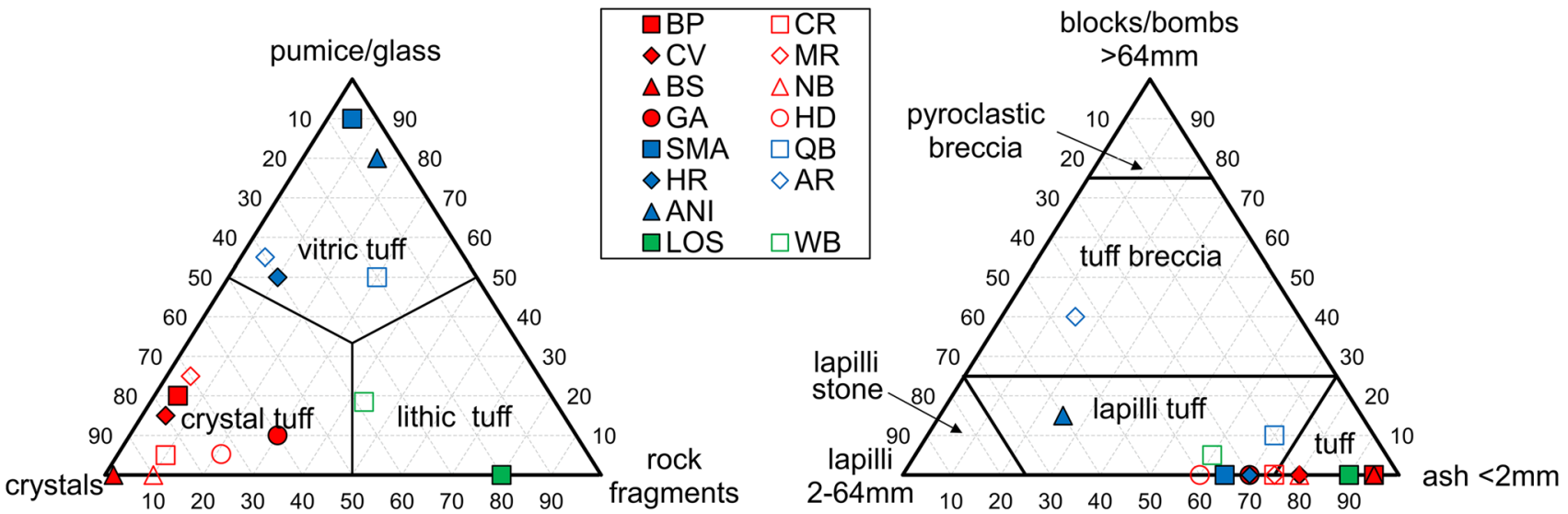

Fig. 3 Tuff classification based on the type of components (Schmid 1981) (left) and based on the size of components (Fisher 1966). The tuffs are colored after their main pyroclastic content: red $=$ crystal tuff, blue $=$ vitric tuff, green $=$ lithic tuff

the vitric tuffs show higher amounts of lapilli and bombs, which are often present in the form of pumice clasts. Most of the tuffs show considerable amounts of swelling clays and/or an abundance of zeolites (Table 2). The vitric tuffs of this study are generally young rocks of Cenozoic age, while crystal tuffs may be multiple times older (up to Permian) (Table 1). It reflects the fact that, over the course of time, the glassy material in the older tuffs, due to its thermodynamic instability, is often altered to fine clay and zeolite crystals (Fisher and Schmincke 2012). The petrographic and petrophysical properties of the tuffs are compiled in Tables 1, 2 and 3. Supplementary data (e.g., XRF, XRD, thin section and SEM photomicrographs) can be found in Pötzl (2020).

The 15 selected tuffs show a high mineralogical heterogeneity, with varying amounts of main components and accessory minerals such as swelling clays or zeolites (Table 2). Past studies on tuffs highlight the strong impact of swelling clays (in this study: clay minerals of the smectite group or with smectitic layers) and zeolites on the strength and 
Environmental Earth Sciences (2022) 81:10

Page 7 of $29 \quad \mathbf{1 0}$

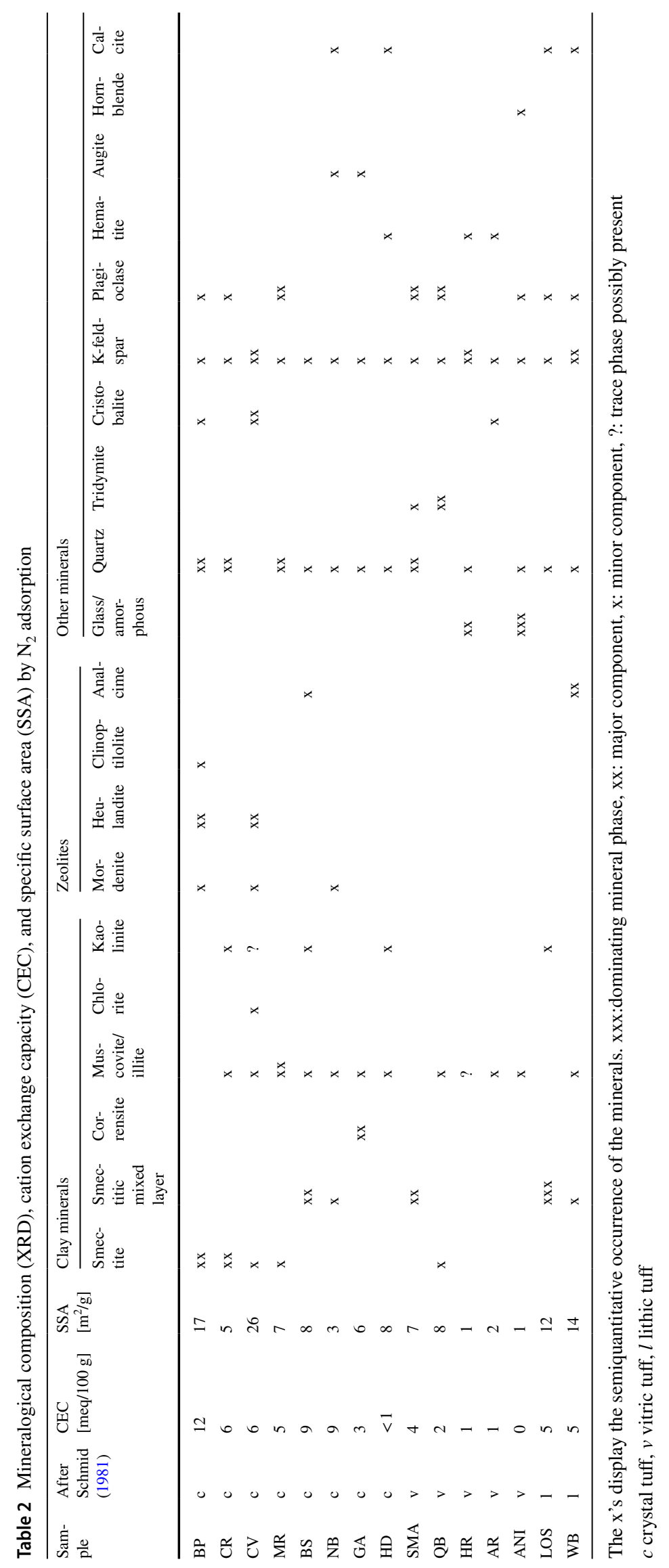

Springer 
Table 3 Summary of the technical parameter of the crystal (left row), vitric (central row), and lithic (right row) tuffs

\begin{tabular}{|c|c|c|c|c|c|c|c|c|c|c|c|c|c|c|c|}
\hline Sample ID & $\mathrm{BP}$ & $\mathrm{CR}$ & CV & $\mathrm{MR}^{\mathrm{b}}$ & $\mathrm{BS}$ & NB & GA & $H D^{c}$ & SMA & $\mathrm{QB}^{\mathrm{b}}$ & $\mathrm{HR}$ & $\mathrm{AR}$ & ANI & LOS & WB \\
\hline Porosity [vol\%] & 14.9 & 31.1 & 29.5 & 15.1 & 14.9 & 25.7 & 21.5 & 25.9 & 40.8 & 46.7 & 33.1 & 53.2 & 35.3 & 16.8 & 36.9 \\
\hline Bulk density $\left[\mathrm{g} / \mathrm{cm}^{3}\right]$ & 1.85 & 1.78 & 1.54 & 2.22 & 2.06 & 1.73 & 2.04 & 1.94 & 1.52 & 1.28 & 1.62 & 1.24 & 1.38 & 2.07 & 1.51 \\
\hline Matrix density $\left[\mathrm{g} / \mathrm{cm}^{3}\right]$ & 2.17 & 2.58 & 2.18 & 2.61 & 2.42 & 2.34 & 2.60 & 2.62 & 2.57 & 2.40 & 2.43 & 2.24 & 2.14 & 2.49 & 2.40 \\
\hline Water absorption [wt\%] & 7 & 14 & 16 & 6 & 6 & 13 & 7 & 9 & 17 & 31 & 15 & 23 & 19 & 7 & 20 \\
\hline Saturation coefficient S & 0.86 & 0.77 & 0.85 & 0.92 & 0.83 & 0.87 & 0.64 & 0.64 & 0.65 & 0.83 & 0.75 & 0.52 & 0.73 & 0.81 & 0.84 \\
\hline Micropores [\%] & 79 & 18 & 88 & 94 & 90 & 37 & 47 & 45 & 10 & 9 & 4 & 5 & 10 & 85 & 14 \\
\hline Capillary pores [\%] & 21 & 82 & 12 & 6 & 10 & 63 & 53 & 55 & 90 & 91 & 96 & 95 & 90 & 15 & 86 \\
\hline Mean pore radius $[\mu \mathrm{m}]$ & 0.05 & 0.20 & 0.04 & 0.04 & 0.03 & 0.14 & 0.11 & 0.18 & 1.50 & 0.74 & 3.93 & 2.24 & 0.87 & 0.04 & 0.51 \\
\hline Pore radii distribution & uu & bi & bi & uu & bi & uu & bi & bi & ue & ue & ue & bi & uu & bi & bi \\
\hline $\mathrm{SSA}\left[\mathrm{m}^{2} / \mathrm{g}\right]$ & 17 & 5 & 26 & 7 & 8 & 3 & 6 & 8 & 7 & 8 & 1 & 2 & 1 & 12 & 14 \\
\hline CEC [meq/100g] & 12 & 6 & 6 & 5 & 9 & 9 & 3 & $<1$ & 4 & 2 & 1 & 1 & $<1$ & 5 & 5 \\
\hline \multicolumn{16}{|l|}{ w-value $\left[\mathrm{kg} / \mathrm{m}^{2} \mathrm{v}(\mathrm{h})\right]$} \\
\hline$x$ & 0.8 & 9.4 & 2.8 & 1.5 & 0.8 & 3.9 & 2.6 & 1.2 & 7.3 & 43.2 & 43.2 & 30.8 & 22.2 & 0.8 & 14.9 \\
\hline Z & 0.8 & 7.1 & 2.6 & 1.6 & 0.5 & 3.8 & 2.7 & 0.9 & 4.7 & 41.1 & 30.9 & 15.2 & 16.3 & 0.7 & 14.2 \\
\hline \multicolumn{16}{|l|}{$\mu$-value } \\
\hline$x$ & 11.9 & 7.5 & 9.2 & 16.2 & 14.4 & 14.4 & 14.5 & 11.5 & 7.4 & 5.4 & 8.1 & 6.6 & 10.4 & 27.9 & 9.1 \\
\hline Z & 11.1 & 8.4 & 10.1 & 19.0 & 14.2 & 14.5 & 14.5 & 11.5 & 8.1 & 4.2 & 9.7 & 8.0 & 15.1 & 13.4 & 9.1 \\
\hline Sorption 95\% RH [wt\%] & 4.5 & 2.6 & 7.9 & 1.8 & 2.9 & 3.5 & 1.3 & 1.8 & 1.2 & 1.2 & 0.1 & 0.1 & 0.8 & 2.9 & 3.2 \\
\hline \multicolumn{16}{|l|}{ hydric exp. $[\mathrm{mm} / \mathrm{m}]$} \\
\hline$x$ & 0.71 & 0.10 & 1.39 & 0.04 & 0.35 & 0.67 & 0.39 & 0.70 & 0.07 & 0.07 & -0.07 & 0.04 & -0.004 & 0.58 & 0.56 \\
\hline Z & 0.96 & 0.24 & 1.68 & 0.16 & 1.57 & 0.76 & 0.59 & 2.24 & 0.23 & 0.11 & -0.13 & 0.03 & -0.01 & 1.22 & 0.65 \\
\hline Max & 1.14 & 0.29 & 2.01 & 0.16 & 2.52 & 0.97 & 0.64 & 7.47 & 0.34 & 0.11 & -0.16 & 0.04 & -0.01 & 1.78 & 0.66 \\
\hline \multicolumn{16}{|l|}{ P-wave velocity $[\mathrm{km} / \mathrm{s}]$} \\
\hline$x$ & 3.3 & 2.8 & 2.7 & 3.8 & 3.9 & 3.1 & 2.7 & 2.9 & 2.7 & 1.6 & 2.9 & 2.1 & 2.9 & 3.7 & 2.5 \\
\hline Z & 3.2 & 2.6 & 2.6 & 3.7 & 3.1 & 3.2 & 2.7 & 2.4 & 2.3 & 1.3 & 2.3 & 1.8 & 2.3 & 2.8 & 2.5 \\
\hline \multicolumn{16}{|c|}{ dyn. Youngs's modulus [GPa] } \\
\hline$x$ & 20 & 14 & 11 & 22 & 31 & 17 & 15 & 16 & 11 & 4 & 14 & 6 & 10 & 28 & 9 \\
\hline Z & 19 & 12 & 10 & 21 & 20 & 18 & 15 & 11 & 8 & 3 & 9 & 5 & 7 & 16 & 9 \\
\hline \multicolumn{16}{|c|}{ Tensile strength dry ßSZ (MPa) } \\
\hline$x$ & $6.9^{\mathrm{a}}$ & - & 3.4 & 5.8 & 8.7 & 5.2 & 4.7 & 3.6 & $3.9^{\mathrm{a}}$ & 0.8 & 3.0 & 3.8 & 2.5 & $6.3^{\mathrm{a}}$ & 1.9 \\
\hline Z & $5.9^{\mathrm{a}}$ & - & 3.0 & 5.3 & 6.4 & 5.9 & 4.8 & 4.0 & $4.0^{\mathrm{a}}$ & 0.7 & 2.3 & 3.3 & 1.8 & $8.3^{\mathrm{a}}$ & 1.5 \\
\hline \multicolumn{16}{|c|}{ Tensile strength sat. ßSZ (MPa) } \\
\hline$x$ & $4.0^{\mathrm{a}}$ & - & - & - & 4.4 & 3.6 & 3.0 & 2.0 & $2.6^{\mathrm{a}}$ & 0.7 & 3.3 & 3.4 & 2.8 & $5.8^{\mathrm{a}}$ & 1.6 \\
\hline Z & $3.1^{\mathrm{a}}$ & - & - & - & 3.4 & 4.1 & 3.2 & 2.4 & $3.0^{\mathrm{a}}$ & 0.6 & 2.5 & 3.0 & 2.2 & $6.7^{\mathrm{a}}$ & 1.3 \\
\hline$\varnothing$ strength reduction & 45 & - & - & - & 49 & 30 & 35 & 41 & 29 & 12 & -9 & 9 & -19 & 14 & 15 \\
\hline \multicolumn{16}{|l|}{ UCS dry [MPa] } \\
\hline$x$ & $66.1^{a}$ & - & - & 76.1 & 107.7 & 70.2 & 59.4 & 43.9 & $31.9^{a}$ & 5.6 & 31.4 & 46.4 & 22.7 & $74.3^{a}$ & 16.0 \\
\hline Z & $53.7^{\mathrm{a}}$ & - & - & 64.6 & 142.1 & 67.8 & 61.6 & 42.0 & $32.6^{a}$ & 4.7 & 31.7 & 36.9 & 22.5 & $58.0^{\mathrm{a}}$ & 17.2 \\
\hline \multicolumn{16}{|l|}{ UCS sat. [MPa] } \\
\hline$x$ & - & - & - & - & 73.7 & 49.4 & 42.3 & 31.9 & 21.4 & 4.2 & 34.0 & 43.4 & 14.6 & 58.1 & 11.8 \\
\hline Z & - & - & - & - & 66.5 & 49.4 & 42.5 & 22.1 & - & 4.0 & 30.2 & 28.9 & 14.9 & 41.7 & 11.1 \\
\hline$\emptyset$ strength reduction & - & - & - & - & 44 & 28 & 30 & 37 & - & 21 & -2 & 13 & 35 & 25 & 31 \\
\hline \multicolumn{16}{|c|}{$\varnothing$ stat. Youngs's modulus [GPa] } \\
\hline dry & - & - & - & 6.3 & 6.4 & 5.3 & 4.9 & 3.9 & - & 1.4 & 4.5 & 3.9 & 3.4 & - & 2.9 \\
\hline wet & - & - & - & - & 5.5 & 4.5 & 3.9 & 3.1 & 2.0 & 2.1 & 4.2 & 3.5 & 2.5 & 4.7 & 2.7 \\
\hline Salt cycles & 65 & 41 & 15 & 40 & $20^{d}$ & $109^{d}$ & $78^{d}$ & 11 & $>85$ & 39 & $>150^{d}$ & $65^{d}$ & $>75^{d}$ & 35 & - \\
\hline
\end{tabular}

SSA specific surface area, CEC cation exchange capacity, $w$ value capillary water absorption, $\mu$ value water vapor diffusion resistance, $T S$ tensile strength, UCS uniaxial compressive strength, $u u$ unimodal unequal, bi bimodal, ue unimodal equal

${ }^{a}$ From Wedekind et al. (2013)

${ }^{\mathrm{b}}$ From Kück (2019)

${ }^{c}$ From Pötzl et al. (2018a)

${ }^{\mathrm{d}}$ From Pötzl et al. (2018b)

weathering behavior (e.g., Heap et al. 2018; Kück et al. 2020a; Lubelli et al. 2018a; Pötzl et al. 2018a, b; Steindlberger 2004, 2007; Wedekind et al. 2013; Wendler 2007). Except for HD, HR, AR and ANI, swelling clays were identified in all investigated tuffs. Furthermore, BP, CV, BS, NB and WB show partly high quantities of zeolitic material.
In general, the vitric tuffs tend to show lower cationexchange capacity (CEC) and specific surface area (SSA) than the crystal and lithic tuffs. Please note that in the literature, Blanca Pachuca (BP) and Cantera Verde (CV) are often described as vitric tuffs with high glass content (e.g., de Pablo-Galán (1986)). In the BP and CV samples of this investigation, the volcanic glass is mostly weathered to clay 
minerals and zeolites, so that these tuffs now classify as crystal tuffs after Schmid (1981). Also, devitrification in Artik Rosa (AR) is already advanced. Figure 4 displays the range of aesthetic, compositional and fabric differences of tuffs by illustrating macrophotographs, thin section photomicrographs and SEM micrographs of four examples from the dataset at the same scale.

As described above, distinct petrographic differences could be identified between the investigated crystal tuffs and vitric tuffs. Since there are only two representatives of lithic tuffs within the dataset (LOS, WB), it is meaningless to assign them as a separate group. For this study, these rocks will be incorporated into the groups with which they share the most affinity, which is crystal tuffs for Loseros (LOS) and vitric tuffs for Weibern (WB). Only future investigation of a larger group of lithic tuffs can determine if this group shows unique and clearly differential petrophysical properties and weathering behavior.

\section{Petrophysical properties and weathering behavior of tuffs: univariate analysis}

In the previous section, the classification system after Schmid (1981) turned out to very effectively concur with clear petrographic distinctions of the tuffs, which is also reflected in the distinct petrophysical properties and weathering behavior, as will be characterized below.

In this section, two sets of data will be described. First, the large dataset compiled from the literature (in which the data of the 15 additional tuffs is included) will be displayed in the form of boxplots. The according mean and median values as well as standard deviation are listed in Table 4 . Second, the data obtained from the 15 representative tuffs of this study will be visualized as red lines next to the plots. A summary of the parameters of the tuffs investigated in detail is compiled in Table 3. The description of the boxplot data will proceed from one parameter to the next, while
Fig. 4 Chromatic, structural and compositional variation of a crystal ash tuff (Blue Sevan), vitric ash-rich lapilli tuff (Hoktemberyan Red), vitric lapilli tuff (Ani Peach) and vitric tuff breccia (Artik Rosa), illustrated in polished sections (left column), thin section photomicrographs (central column) and scanning electron photomicrographs (right column)

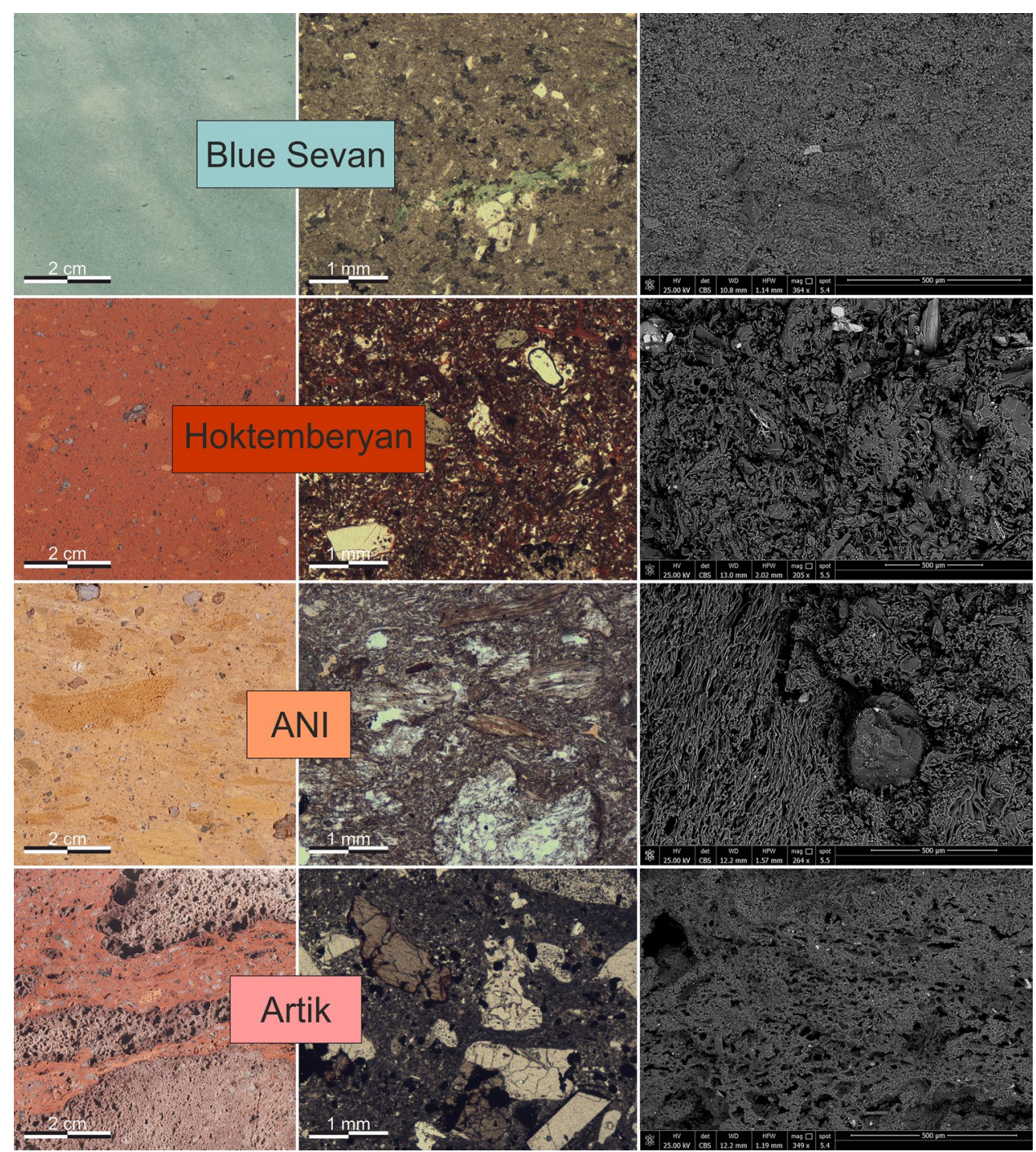


describing the large dataset first and subsequently the 15 representative tuffs.

A first observation is an asymmetrical distribution and a wide scattering in most of the plotted parameters, which is displayed by the high standard deviation (Table 4). Properties with high standard deviation are often accompanied by outliers towards higher values (e.g., water vapor diffusion resistance, UCS, or hydric expansion) and show a positive skew. The only exceptions with negative skew are the matrix density and saturation coefficient (Fig. 5). In the following, the median value is considered to be more robust to skewed data and gives a more realistic picture of the data distribution.

The bulk density of 511 data points is characterized by a wide scattering between 0.91 and $2.48 \mathrm{~g} / \mathrm{cm}^{3}$, with a median value of $1.66 \mathrm{~g} / \mathrm{cm}^{3}$ (outliers 0.81 and $2.70 \mathrm{~g} / \mathrm{cm}^{3}$ ) (Fig. 5). The median of the matrix density $(n=260)$ is $2.51 \mathrm{~g} / \mathrm{cm}^{3}$, with min-max values of $2.05-2.87 \mathrm{~g} / \mathrm{cm}^{3}$ and several outliers down to $1.82 \mathrm{~g} / \mathrm{cm}^{3}$. Note that the crystal tuffs in Table 3 are generally characterized by higher bulk densities $\left(1.54-2.22 \mathrm{~g} / \mathrm{cm}^{3}\right)$ than vitric tuffs $\left(1.24-1.62 \mathrm{~g} / \mathrm{cm}^{3}\right)$.

The boxplot displaying the effective porosity of 528 data points shows that tuffs typically possess a wide range of porosities between 1.5 and $56.5 \mathrm{vol} \%$, with outliers exceeding values up to 64 vol\% (Fig. 5). Considering the wide scattering of values, the median of $28.0 \mathrm{vol} \%$ and mean of 28.9 vol\% are relatively close to each other, indicating a symmetrical distribution. The crystal tuffs of this study tend to show intermediate to high porosities between 14.9 and 31.1 vol\%, whereas the vitric tuffs exhibit very high porosities, starting with 33.1 vol\% and reaching up to 53.2 vol\% (AR) (Table 3).

With a median of $0.3 \mu \mathrm{m}$, the values of $(n=156)$ mean pore radii show a distinct positive skew, with $50 \%$ of the data points located in a relatively small IQR between 0.06 and $0.9 \mu \mathrm{m}$ (Fig. 5). Including the extreme values, tuffs show mean pore radii ranging from the nanometer range $(4 \mathrm{~nm})$ up to $1.98 \mu \mathrm{m}$. Many outliers exceed mean pore radii up to $10.5 \mu \mathrm{m}$. A wide scattering of data can also be observed for the fraction of micropores $(n=127)$, which almost covers the whole range from 0 to $100 \%$ ( $\min 2.17 \%$; $\max 94 \%$; median $25 \%$; outliers up to $97 \%$ ). An extreme example is the Hoktemberyan Red (HR) with a mean pore radius of $3.93 \mu \mathrm{m}$ and $96 \%$ of capillary pores (Table 3). Other extreme examples are the Blanca Pachuca (BP), Loseros (LOS), Cantera Verde (CV) and Blue Sevan (BS) with up to 79-90\% micropores. In general, the crystal tuffs show much higher fractions of micropores (37-94\%) and accordingly smaller mean pore radii $(0.03-0.20 \mu \mathrm{m})$ in comparison to the vitric tuffs (micropores 4-10\%; mean pore radii 0.74-3.93 $\mu \mathrm{m}$ ).

Fifteen samples are certainly not sufficient to derive general laws, but some clear trends can be noted when characterizing the pore size distribution after the classification scheme of Ruedrich and Siegesmund (2006): (1) only vitric tuffs show unimodal equal pore size distributions (although only slightly sometimes); (2) crystal tuffs are exclusively

Table 4 Mean, median, and standard deviations of the data distribution from the literature data compilation (references in Table 6)

\begin{tabular}{|c|c|c|c|c|c|c|c|c|c|c|c|c|}
\hline \multirow{2}{*}{$\frac{}{n}$} & \multicolumn{3}{|c|}{$\begin{array}{l}\text { Bulk density }[\mathrm{g} / \\
\left.\mathrm{cm}^{3}\right]\end{array}$} & \multicolumn{2}{|c|}{$\begin{array}{l}\text { Matrix density }[\mathrm{g} / \\
\left.\mathrm{cm}^{3}\right]\end{array}$} & \multicolumn{2}{|c|}{ Porosity [vol\%] } & \multicolumn{2}{|c|}{$\begin{array}{l}\text { Mean pore radius } \\
{[\mu \mathrm{m}]}\end{array}$} & \multicolumn{2}{|c|}{ Micropores [\%] } & $\overline{\mathrm{SSA}\left[\mathrm{m}^{2} / \mathrm{g}\right]}$ \\
\hline & \multicolumn{3}{|c|}{511} & \multicolumn{2}{|l|}{260} & \multicolumn{2}{|l|}{528} & \multicolumn{2}{|l|}{156} & \multicolumn{2}{|l|}{127} & 66 \\
\hline Median & \multicolumn{3}{|c|}{1.66} & \multicolumn{2}{|l|}{2.51} & \multicolumn{2}{|l|}{28.0} & \multicolumn{2}{|l|}{0.30} & \multicolumn{2}{|l|}{25} & 8.6 \\
\hline Mean & \multicolumn{3}{|c|}{1.68} & \multicolumn{2}{|l|}{2.48} & \multicolumn{2}{|l|}{28.9} & \multicolumn{2}{|l|}{0.87} & \multicolumn{2}{|l|}{34} & 12.6 \\
\hline \multirow[t]{2}{*}{ Std Dev } & & 0.32 & & 0.17 & & 11.4 & & 1.55 & & 27 & & 15.3 \\
\hline & \multicolumn{2}{|c|}{ TS dry $[\mathrm{MPa}]$} & \multicolumn{2}{|c|}{ TS sat. [MPa] } & \multicolumn{2}{|c|}{ UCS dry [Mpa] } & \multicolumn{2}{|c|}{ UCS sat. [Mpa] } & \multicolumn{2}{|c|}{$\begin{array}{l}\text { P-wave velocity } \\
\text { dry }[\mathrm{km} / \mathrm{s}]\end{array}$} & $\begin{array}{l}\text { Dyn. Young's } \\
\text { mod. [GPa] }\end{array}$ & $\begin{array}{l}\text { Stat. } \\
\text { Young's } \\
\text { mod. [GPa] }\end{array}$ \\
\hline$n$ & 150 & & 50 & & 374 & & 63 & & 262 & & 66 & 80 \\
\hline Median & 3.1 & & 2.0 & & 21.0 & & 12.5 & & 2.37 & & 12.4 & 4.7 \\
\hline Mean & 4.0 & & 2.3 & & 30.2 & & 17.9 & & 2.45 & & 14.6 & 7.2 \\
\hline \multirow[t]{2}{*}{ Std Dev } & 4.1 & & 1.7 & & 32.2 & & 18.5 & & 0.66 & & 9.8 & 8.9 \\
\hline & & \multicolumn{2}{|c|}{$\begin{array}{l}\text { Water absorption } \\
\text { [wt } \% \text { ] }\end{array}$} & \multicolumn{2}{|c|}{$\begin{array}{l}\text { Saturation coeff. } \\
S[-]\end{array}$} & \multicolumn{2}{|c|}{$w$ value $\left[\mathrm{kg} / \mathrm{m}^{2} \sqrt{\mathrm{h}}\right]$} & \multicolumn{2}{|c|}{$\mu$ value $[-]$} & \multicolumn{2}{|c|}{$\begin{array}{l}\text { Sorption } 95 \mathrm{rh} \\
{[\mathrm{wt} \%]}\end{array}$} & $\begin{array}{l}\text { Mean hydric } \\
\text { exp. }[\mathrm{mm} / \mathrm{m}]\end{array}$ \\
\hline$n$ & \multicolumn{3}{|c|}{311} & 92 & & 161 & & 85 & & 60 & & 131 \\
\hline Median & & 16.1 & & 0.75 & & 11.2 & & 12.4 & & 1.8 & & 0.45 \\
\hline Mean & & 16.6 & & 0.72 & & 17. & & 18.1 & & 2.1 & & 0.78 \\
\hline Std Dev & & 8.4 & & 0.16 & & 19. & & 16.4 & & 1.9 & & 0.99 \\
\hline
\end{tabular}

$n$ number of data points, SSA specific surface area, $w$ value capillary water uptake, $\mu$ value water vapor diffusion resistance, $T S$ tensile strength, UCS uniaxial compressive strength 

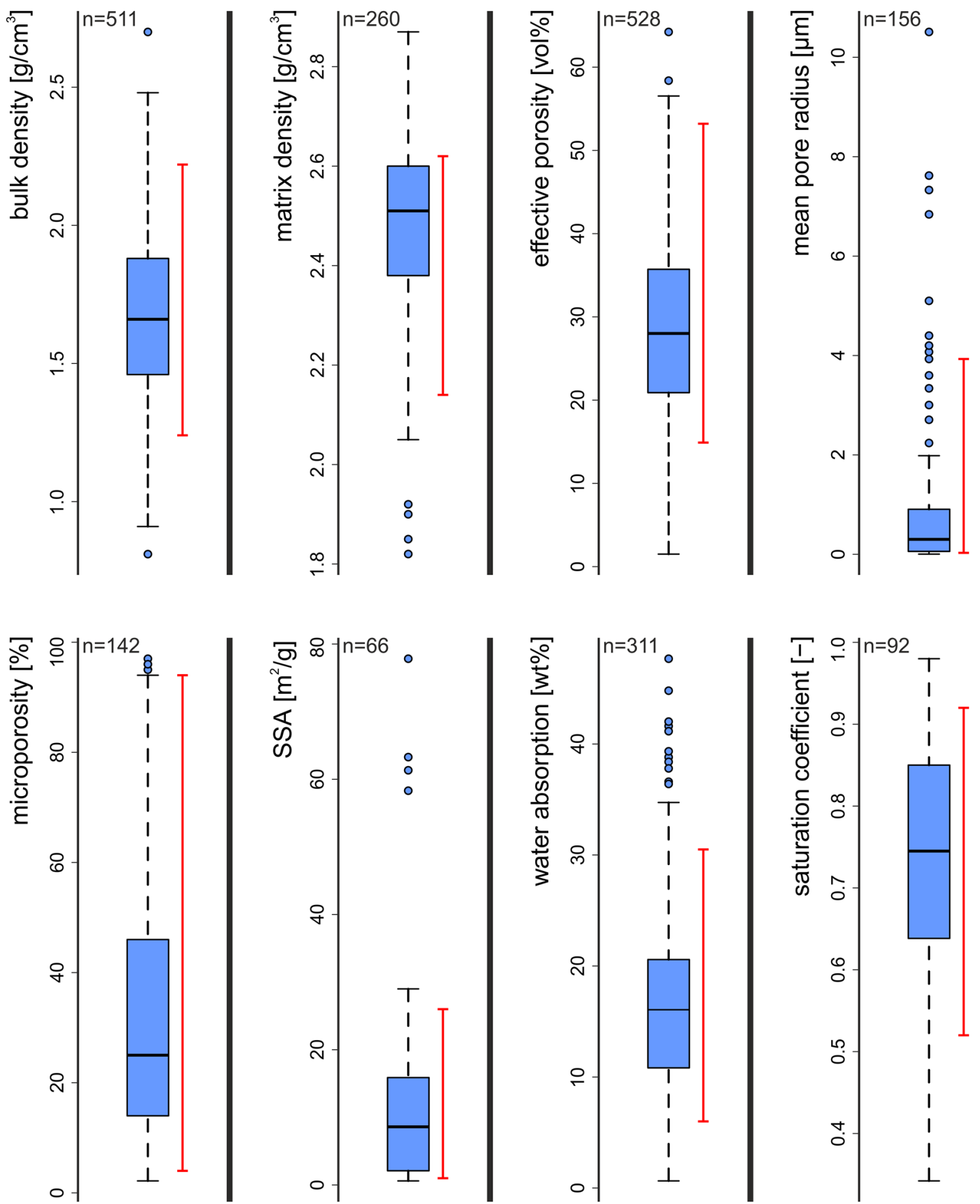

Fig. 5 Box-whisker plots of the pore space and total water absorption properties from $n=$ number of tuffs (references in Table 6). SSA specific surface area. The blue dots represent outliers; the red line repre-

characterized by unimodal unequal or bimodal distributions; (3) lithic tuffs show bimodal distribution. A bimodal distribution is the most volatile of the three, as it can be observed in all three types of tuff (Table 3; Fig. 6).
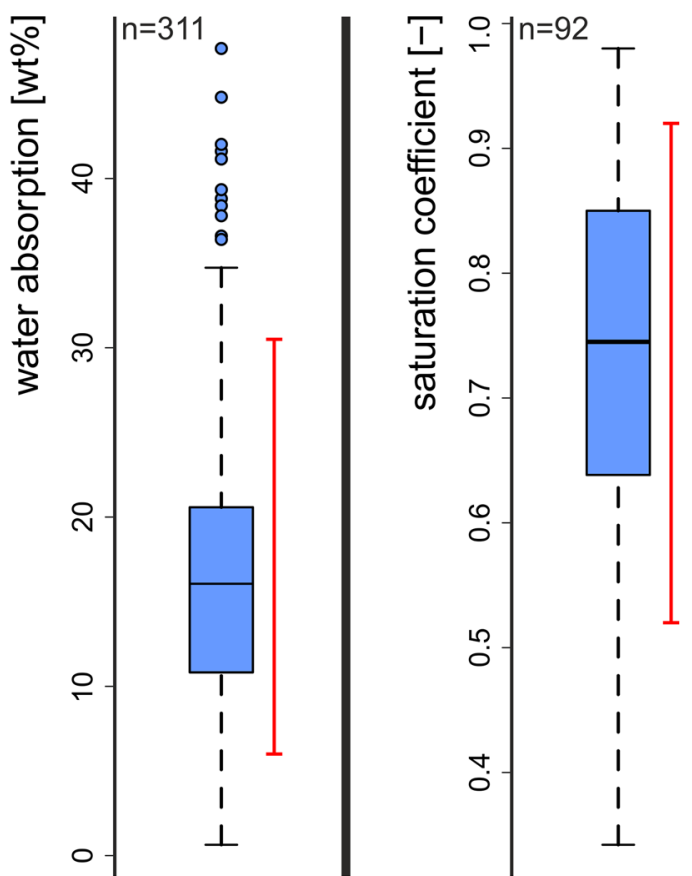

sents the range of properties of the 15 tuffs of this study investigated in more detail

Under atmospheric conditions, tuffs $(n=311)$ absorb on average $16.6 \mathrm{wt} \%$ water (median $16 \mathrm{wt} \%$ ). However, the scattering of the data is wide and water absorption values from barely any absorption (0.6 wt \%) up to $34.7 \mathrm{wt} \%$ are within the range of the whiskers (Fig. 5). Outliers display 
tuffs that even absorb up to $47.7 \mathrm{wt} \%$ water under atmospheric conditions. The related saturation coefficients after Hirschwald (1912) show values starting from 0.34 up to 0.98 , with an average of 0.72 and a median of $0.75(n=92)$. Natural stones with $S$ values $<0.75$ are considered frost resistant, $S$ values $>0.75$ and $<0.9$ indicate uncertain frost resistance, and $S>0.9$ is not considered to be frost resistant. The average tuff with a saturation coefficient $<0.75$ is therefore categorized as barely frost resistance after Hirschwald (1912) and looking at the boxplot in Fig. 5, many tuffs are classified as not frost resistant building material. The Queretaro Blanco (QB) is an example of extreme water absorption under atmospheric conditions (31 wt \%). In contrast, the Mitla Rosa (MR) and Blue Sevan (BS) show the lowest absorption (6 wt \%). All of these extreme examples exhibit $S$ values $>0.75$ (up to 0.92 ) and are not considered frost resistant. Regarding water absorption and frost resistance, clear differences can be observed for both crystal and vitric tuffs of this study. While the vitric tuffs tend to a higher water absorption (15-31 wt\%), crystal tuffs absorb relatively little water (6-16 wt\%). With the exception of Golden Armenia (GA) and Hilbersdorf (HD), all crystal tuffs show high saturation coefficients $(S>0.75)$, meaning that frost resistance of the material is uncertain or not existent (Hirschwald 1912). On the other hand, with the exception of Queretaro Blanco (QB), saturation coefficients of vitric tuffs indicate frost resistance of the material.

The specific surface area (SSA) of tuffs $(n=66)$, which is of particular importance for adsorption processes and reactions on the materials surface, ranges from 0.6 to $29 \mathrm{~m}^{2} / \mathrm{g}$ (median $8.6 \mathrm{~m}^{2} / \mathrm{g}$ ), but also extreme outliers with values up to $77.8 \mathrm{~m}^{2} / \mathrm{g}$ are recorded (Fig. 5). An increased SSA in tuffs is often accompanied by increased clay mineral and/ or zeolite content (Kück et al. 2020a). The hygroscopic water sorption, water vapor diffusion resistance and capillary water absorption show similar distributions (Fig. 7). With a median of $1.76 \mathrm{wt} \%$, most of the hygroscopic sorption values $(n=60)$ are between 0.06 and $4.86 \mathrm{wt} \%$, but also extreme outliers of up to $7.9 \mathrm{wt} \%$ (Cantera Verde (CV)) can be observed. Examples of extremely low hygroscopic water sorption are Hoktemberyan Red (HR) and Artik Rosa (AR) (both $0.1 \%$ ). The highest values are shown by tuffs that are rich in zeolites and swelling clays (compare Table 2). As shown in Tables 2 and 3, crystal tuffs tend to higher SSA $\left(3-26 \mathrm{~m}^{2} / \mathrm{g}\right)$ and CEC values $(<1-12 \mathrm{meq} / 100 \mathrm{~g})$ than the vitric tuffs (SSA $1-8 \mathrm{~m}^{2} / \mathrm{g} ; \mathrm{CEC}<1-4 \mathrm{meq} / 100 \mathrm{~g}$ ). Hygroscopic water sorption of the vitric tuffs is very low (0.1-1.2 wt \%), while the crystal tuffs of this study show values that are multiple times higher (1.3-7.9 wt\%).

The values of the water vapor diffusion resistance coefficient $\mu(n=85)$ show a median of 12.4 , with most values located between 4.8 and 29.5 (Fig. 7). Extreme outliers of up to three times the maximum value (93) can be observed. The Loseros tuff (LOS) is an example of very high $\mu$ value, with 27.9 in $X$ direction. The Queretaro Blanco (QB), like most vitric tuffs, shows very low resistance against water vapor diffusion (4.2 in $Z$ direction). The crystal tuffs show moderate resistance towards water vapor diffusion, with $\mu$ values up to 19 . Regarding the capillary water absorption, values $(n=161)$ range between 0.04 and $61.1 \mathrm{~kg} / \mathrm{m}^{2} \sqrt{\mathrm{h}}$, with a median of $11.2 \mathrm{~kg} / \mathrm{m}^{2} \sqrt{ } \mathrm{h}$. Outliers reach $w$ values of up to $94.9 \mathrm{~kg} / \mathrm{m}^{2} \sqrt{\mathrm{h}}$. In this study, high capillary water
(II) unimodal unequal
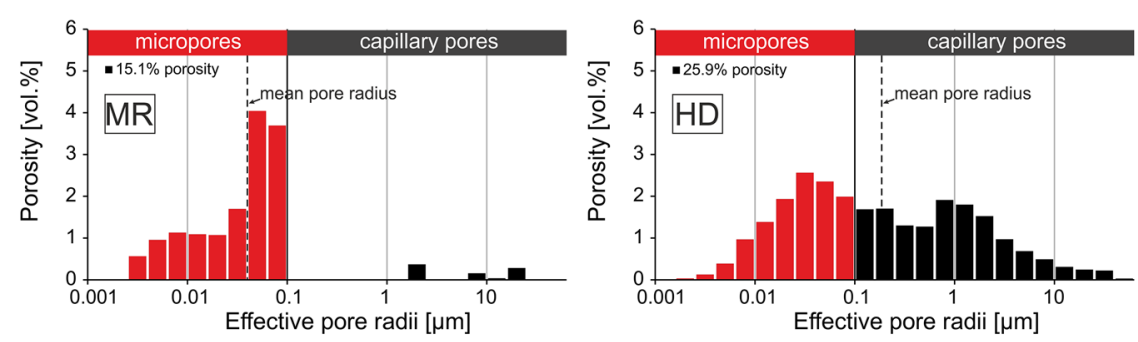

ratio of capillary pores

\section{(1) unimodal equal}
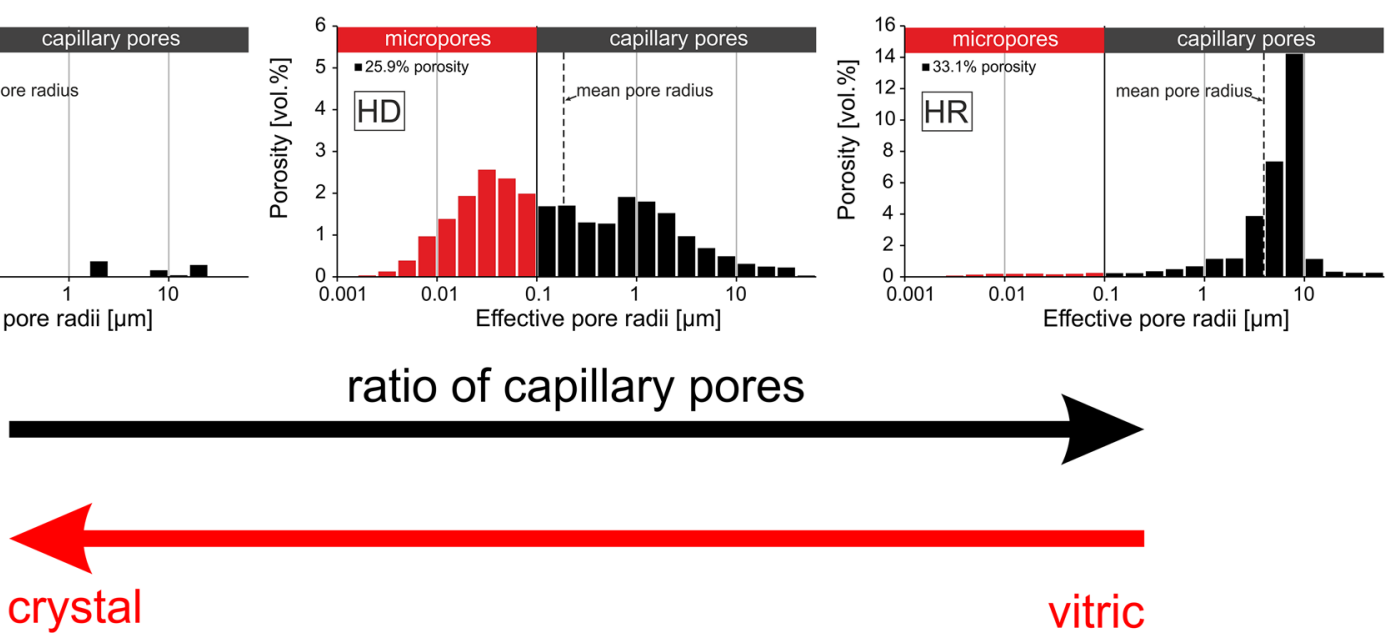

Fig. 6 Representative pore radii distribution types according to Ruedrich and Siegesmund (2006) observed in three tuffs and schematic relation to the fragmental composition of the rock and ratio of capil- lary pores as observed in the dataset. The arrows display an increasing ratio of capillary pores and crystal content typical for either of the pore radii types 

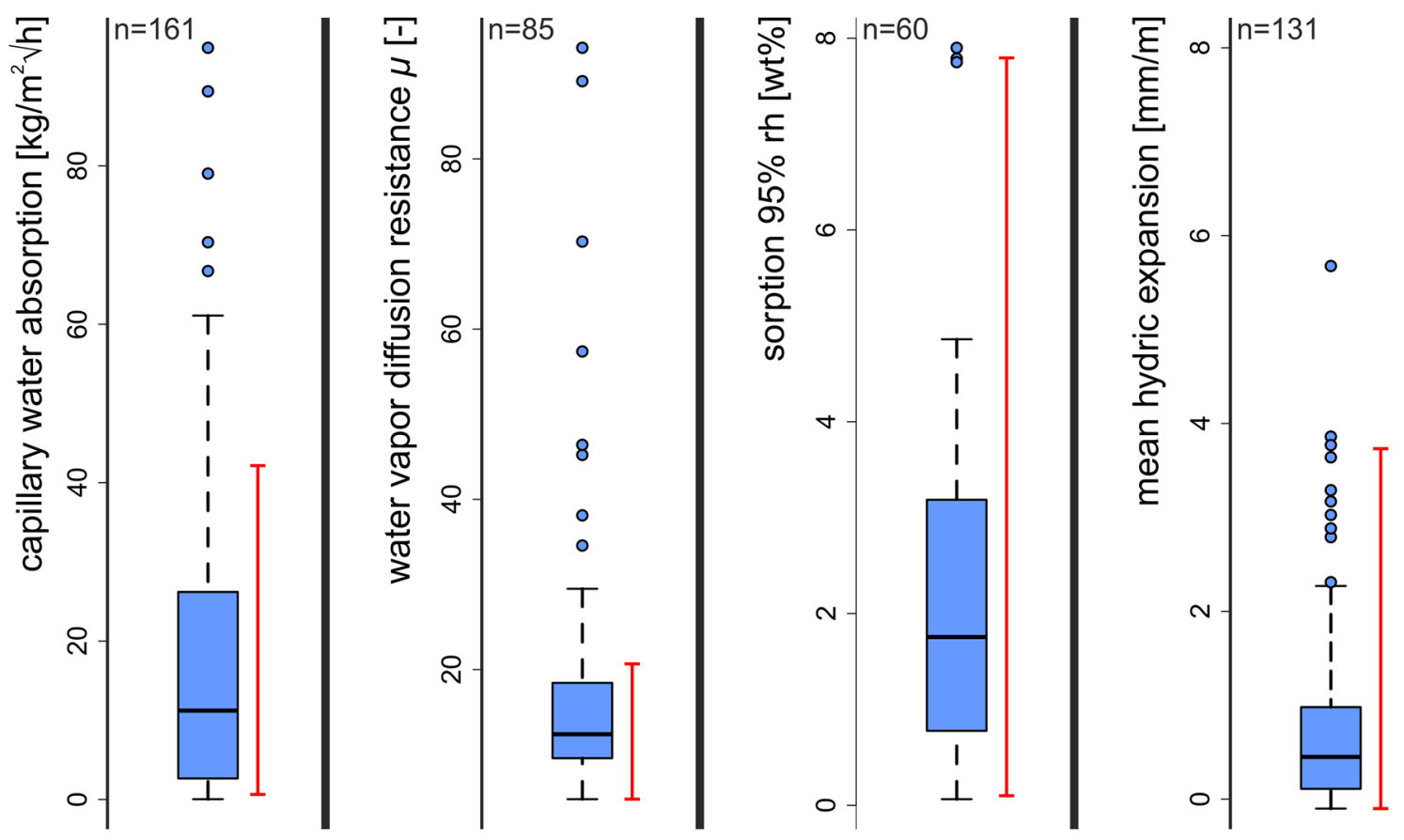

Fig. 7 Box-whisker plots of the water transport, retention, and expansion properties from $n=$ number of tuffs (references in Table 6). The blue dots represent outliers; the red line represents the range of properties of the 15 tuffs of this study investigated in more detail

uptake is especially shown by the vitric tuffs, with Queretaro Blanco (QB) and Hoktemberyan Red (HR) on the upper end (both $43.2 \mathrm{~kg} / \mathrm{m}^{2} \sqrt{ } \mathrm{h}$ in $X$ direction), while low values are shown by crystal tuffs, with extreme low values by Blanca Pachuca (BP), Loseros (LOS), Blue Sevan (BS), and Hilbersdorf (HD) (BS lowest with $0.45 \mathrm{~kg} / \mathrm{m}^{2} \sqrt{\mathrm{h}}$ in $Z$ direction). A partly pronounced anisotropic behavior of the tuffs, with usually higher capillary water absorption and lower water vapor diffusion resistance parallel to the bedding plane ( $X$ direction), indicates a better connection of the pore network in this direction.

The ultrasonic velocity of 262 data points ranges between 0.96 and $4.05 \mathrm{~km} / \mathrm{s}$, with a median of $2.37 \mathrm{~km} / \mathrm{s}$ and outliers of up to $4.38 \mathrm{~km} / \mathrm{s}$ (Fig. 8). Via ultrasonic measurement, the dynamic Young's modulus, which is proportional to the rock strength, can be obtained (Siegesmund and Dürrast 2011). Tuffs $(n=66)$ show a median value of $12.4 \mathrm{GPa}$, with a minimum of $0.9 \mathrm{GPa}$ and maximum of $39 \mathrm{GPa}$. In this study, the lowest ultrasonic velocities and corresponding dynamic Young's moduli are shown by vitric tuffs, especially the Artik Rosa (AR) and Queretaro Blanco (QB) (QB down to $1.3 \mathrm{~km} / \mathrm{s}$ and $2.8 \mathrm{GPa}$ in $Z$ direction). Particularly, high values are shown by Loseros (LOS) and crystal tuffs like Mitla Rosa (MR) and Blue Sevan (BS) with up to $3.9 \mathrm{~km} / \mathrm{s}$ and $31.5 \mathrm{GPa}$.

Characterizing mechanical properties like the tensile or compressive strength are of particular importance for the estimation of the rock durability. Compared to other rock types, tuff rocks exhibit relatively low mechanical strength values (Mosch and Siegesmund 2007). Under dry conditions, the tensile strength of 150 tuffs is between 0.2 and 8.0 MPa, with a median of 3.1 MPa. Extreme outliers reach values up to $25.7 \mathrm{MPa}$ (Fig. 8). Under water saturated conditions, the tensile strength values of 50 data points are nearly halved (median 2.0 MPa; min-max 0.1-4.7 MPa). Few outliers reach values up to $8.5 \mathrm{MPa}$.

The uniaxial compressive strength (UCS), as one of the most frequently used parameters for the characterization of the rock strength, shows an extraordinary high standard deviation under dry conditions (Table 4). With a median of 21.0 $\mathrm{MPa}$ and a mean of $30.2 \mathrm{MPa}$, the values of $n=374$ tuffs range between 0.7 and $73 \mathrm{MPa}$. A high amount of outliers exceed these values and reach UCS of up to $245 \mathrm{MPa}$. From the investigated tuffs, Blue Sevan (BS) exceeds the maximum UCS with an average of $124.9 \mathrm{MPa}$. Under water saturated conditions, the mean UCS of $n=63$ tuffs is significantly lowered (0.2-49.4 MPa; median $12.5 \mathrm{MPa}$; mean 17.9 MPa). Almost half of the additionally investigated tuffs of this study show a strength reduction of more than $1 / 3$ of their original value, both in TS and UCS measurements (Table 3). Extraordinary high strength reduction is primarily shown by the crystal tuffs, especially Blanca Pachuca (BP), Blue Sevan (BS) and Hilbersdorf (HD), with a loss in strength of almost 50\%. Vitric tuffs show less strength reduction. Special cases are the Hoktemberyan Red (HR) and (in parts) the Ani Peach (ANI) tuff, which show opposite 

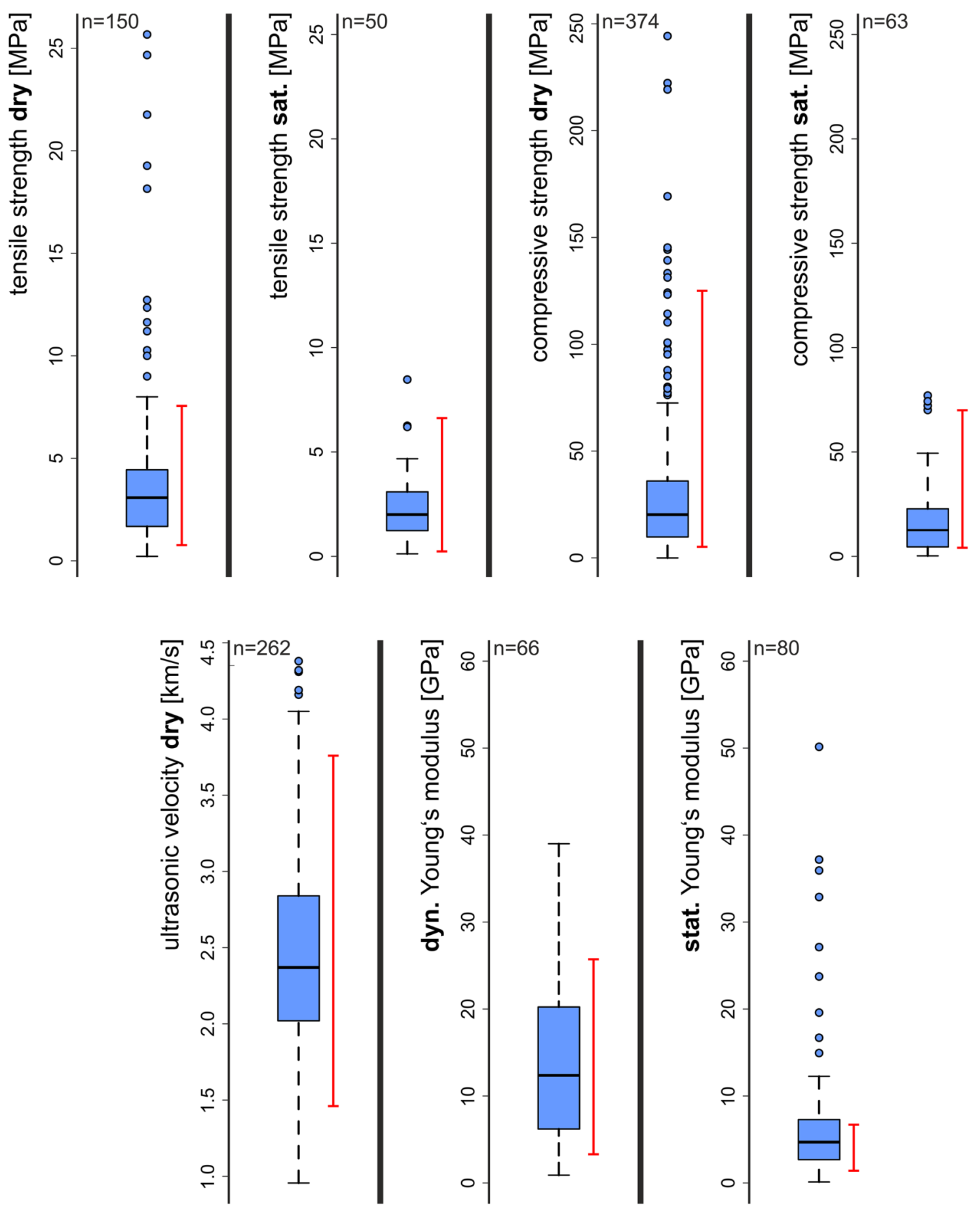

Fig. 8 Box-whisker plots of the mechanical and elastic properties from $n=$ number of tuffs (references in Table 6). The blue dots represent outliers; the red line represents the range of properties of the 15 tuffs of this study investigated in more detail

behavior, with slight strength increase due to water saturation. Particularly low strength values in the dataset are presented by the Queretaro Blanco (QB), with an average tensile strength around $0.8 \mathrm{MPa}$ and a UCS of 4.6 MPa. The static Young's modulus, as a parameter for the resistance against deformation of $(n=80)$ tuffs, was obtained from the UCS measurements and shows a similar trend. Also, here, the wide range of values (0.1-12.3 GPa; median $4.7 \mathrm{GPa})$ is exceeded by extreme outliers up to $50.2 \mathrm{GPa}$. To sum up, the crystal tuffs of this study generally show higher strength values and static Young's moduli than the vitric tuffs, but also higher loss in strength due to water saturation (compare Table 3). 
The characterization of the hydric expansional behavior of the tuffs gives a proper estimation about future response of the material to changing environmental conditions and weathering effects. As the boxplot in Fig. 7 displays, the response of $(n=131)$ tuffs to water immersion is usually an expansional process with mean values around $0.8 \mathrm{~mm} / \mathrm{m}$ (median $0.5 \mathrm{~mm} / \mathrm{m}$ ) and a maximum of $2.3 \mathrm{~mm} / \mathrm{m}$. Outliers expand up to $5.7 \mathrm{~mm} / \mathrm{m}$ (Hilbersdorf (HD)), but also negative expansion $(-0.1 \mathrm{~mm} / \mathrm{m})$ is recorded, e.g., Hoktemberyan Red (HR), Ani Peach (ANI) and in parts San Miguel el Alto (SMA) as well as some Artik (AR) types. Some specimens of the Hilbersdorf tuff (HD) expand up to $7.5 \mathrm{~mm} / \mathrm{m}$. A general observation on the tuffs of this study is: low hydric expansion (up to contractional behavior) in vitric tuffs; high expansion values in crystal tuffs. An important characteristic that is shared by all tuffs, is a partly strong anisotropic behavior of the material, with higher expansion perpendicular to the bedding plane ( $Z$ direction) (Table 3 ).

Salt bursting tests identify the resistance of the material to crystallization pressure of salts. Sousa et al. (2018) give a detailed overview on controlling factors of salt weathering in granitoids. López-Doncel et al. (2016) investigated the main factors influencing the salt weathering in volcanic tuffs. A critical literature review on salt crystallization tests and new ideas to overcome existing limitations can be found in Lubelli et al. (2018b). In many investigations, especially in timely limited thesis works (e.g., Molina-Maldonado 2016; Teipel 2020; Wittenborn 2015), the salt bursting tests are not continued after a certain amount of cycles and results are extrapolated from the status quo. Individual stones, however, may show significant deterioration only after a high amount of cycles (e.g., Pötzl et al. 2018b; Sousa et al. 2018). An extrapolation of the results may be reasonable within individual datasets, but does aggravate the overall comparability with the results of other studies. Some studies extrapolated after 40 cycles; others stopped testing after 150 cycles. The illustration of the range of absolute values in form of a boxplot is therefore misleading and was consequently not done in this study.

Within the dataset of this study, the 15 tuffs show a wide range of different responses and resistance towards salt weathering (Table 3). An overall trend indicates that, on average, crystal tuffs obtain lower resistance (11-109 salt cycles; mean 47 cycles) and vitric tuffs higher resistance (39 to $>150$ salt cycles; mean $>83$ cycles).

\section{Petrophysical properties and weathering behavior: bivariate analysis}

In the following, regression analyses of some basic parameters typically investigated for building stones are displayed and discussed. These correlations can be useful for understanding the mutual dependence of the parameters and to estimate certain parameters using others (Liu et al. 2019; Pappalardo et al. 2017; Vernik et al. 1993) In comprehensive statistical studies on other natural building stones like granitoids (Sousa 2014) or sandstones (Stück et al. 2013), the pore space properties showed to have a significant influence on strength values and weathering behavior and are therefore of particular interest.

Both bulk density and porosity are two pore space properties which are fundamental for many investigations on engineering properties of building stones. On 491 data pairs, they show a strong negative linear relationship $(r=-0.81)$, meaning that high porosity is related to low bulk density and vice versa (Fig. 9). The average value of the $80 \%$ confidence ellipsoid amounts to $1.66 \mathrm{~g} / \mathrm{cm}^{3}$ bulk density and $30 \mathrm{vol} \%$ porosity. Both bulk density and porosity show a strong linear correlation with the water absorption behavior under atmospheric conditions of tuffs $(r=-0.92(n=299)$ and $0.85(n=302)$, respectively). While at higher bulk densities, the water absorption decreases, an increasing porosity is accompanied by an increasing water absorption (Fig. 9). The mean values of the confidence ellipsoids are at $16.7 \%$ water absorption and a bulk density of $1.67 \mathrm{~g} / \mathrm{cm}^{3}$ or a porosity of $27.9 \mathrm{vol} \%$.

Although the $(n=258$ and $n=262)$ data pairs are moderately scattered, both bulk density and porosity show a linear relationship with the ultrasonic velocity $(r=0.65$ and -0.56 , respectively) (Fig. 9). A positive linear relation with a correlation coefficient of $r=0.67$ is displayed by 68 data pairs of the bulk density and the dynamic Young's modulus. While the mean bulk density of $1.79 \mathrm{~g} / \mathrm{cm}^{3}$ amounts to $13.8 \mathrm{GPa}$ in the $80 \%$ confidence ellipsoid, higher bulk densities correlate with increased dynamic moduli of elasticity (Fig. 9).

The relationship of the effective porosity and bulk density with strength parameters like compressive and tensile strength is of exponential nature (Fig. 10). With increasing bulk density, the compressive and tensile strength are increasing exponentially, whereas increasing porosity is accompanied by an exponential decrease of strength (Fig. 10). Correlation coefficients are usually higher for regressions against bulk density and therefore display a stronger relationship (e.g., bulk density vs. UCS: $r=0.84$; porosity vs. UCS: $r=0.75$ ). Both bulk density and porosity show a less pronounced but still moderate to strong exponential correlation with the tensile strength $(r=0.68$ and -0.65 , respectively). The ultrasonic velocity strongly correlates with the strength values, showing exponential increase of strength with increasing ultrasonic velocity (Fig. 10). Its relation, however, is stronger with the tensile strength $(r=0.82)$ than with the compressive strength $(r=0.72)$. Exponential decrease of compressive strength is related to an increased capacity of water absorption of the material (Fig. 11). The coefficient of correlation for $n=253$ data pairs is strong $(r=-0.82)$. 

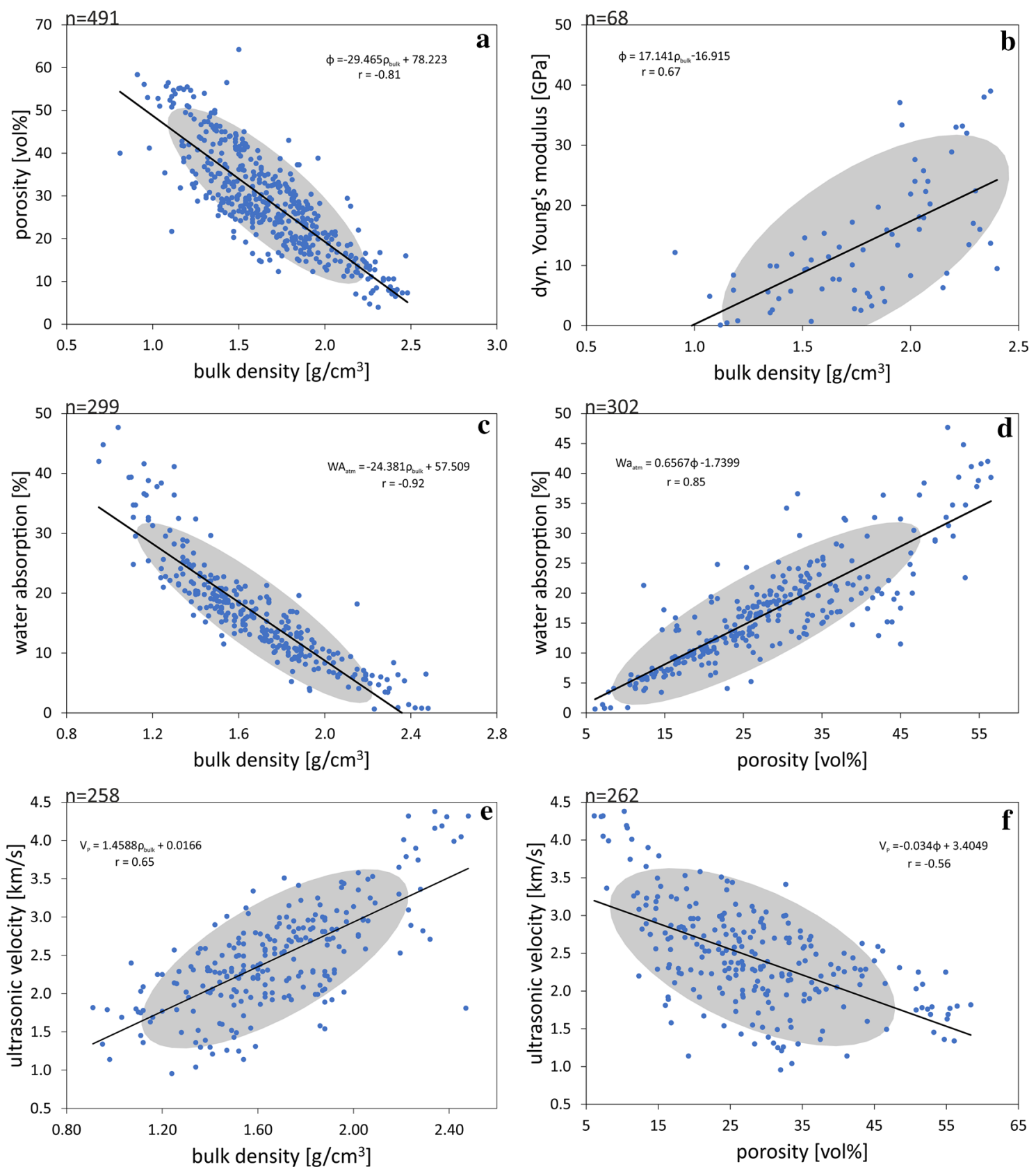

Fig. 9 Regression analysis of different rock properties with trendlines and $r$ values. The grey ellipses predict an $80 \%$ probability of the data. Data taken from references in Table 6 (data of this study included). $n=$ number of data pairs

Other, weaker and less pronounced correlations can be found for some pore space properties with the water transport properties and expansional behavior of tuff (Fig. 11). Regression analysis indicates an exponential relationship between $n=98$ data pairs of the capillary water absorption and the fraction of micropores. The correlation coefficient, however, describes only a moderate relationship between these parameters $(r=-0.56)$. Between the fraction of micropores and the water vapor diffusion resistance, the correlation is even weaker $(r=0.49 ; n=80)$, while showing a barely linear trend. In contrast, the porosity shows a distinct negative exponential relationship with the water vapor diffusion resistance and a strong correlation coefficient of $r=-0.79$. However, regarding capillary water absorption and water vapor diffusion resistance, the data are fairly scattered and confidence ellipses are wide. Consequently, both porosity and fraction of micropores should be used with caution to estimate general trends of the water transport and retention properties of tuffs. 

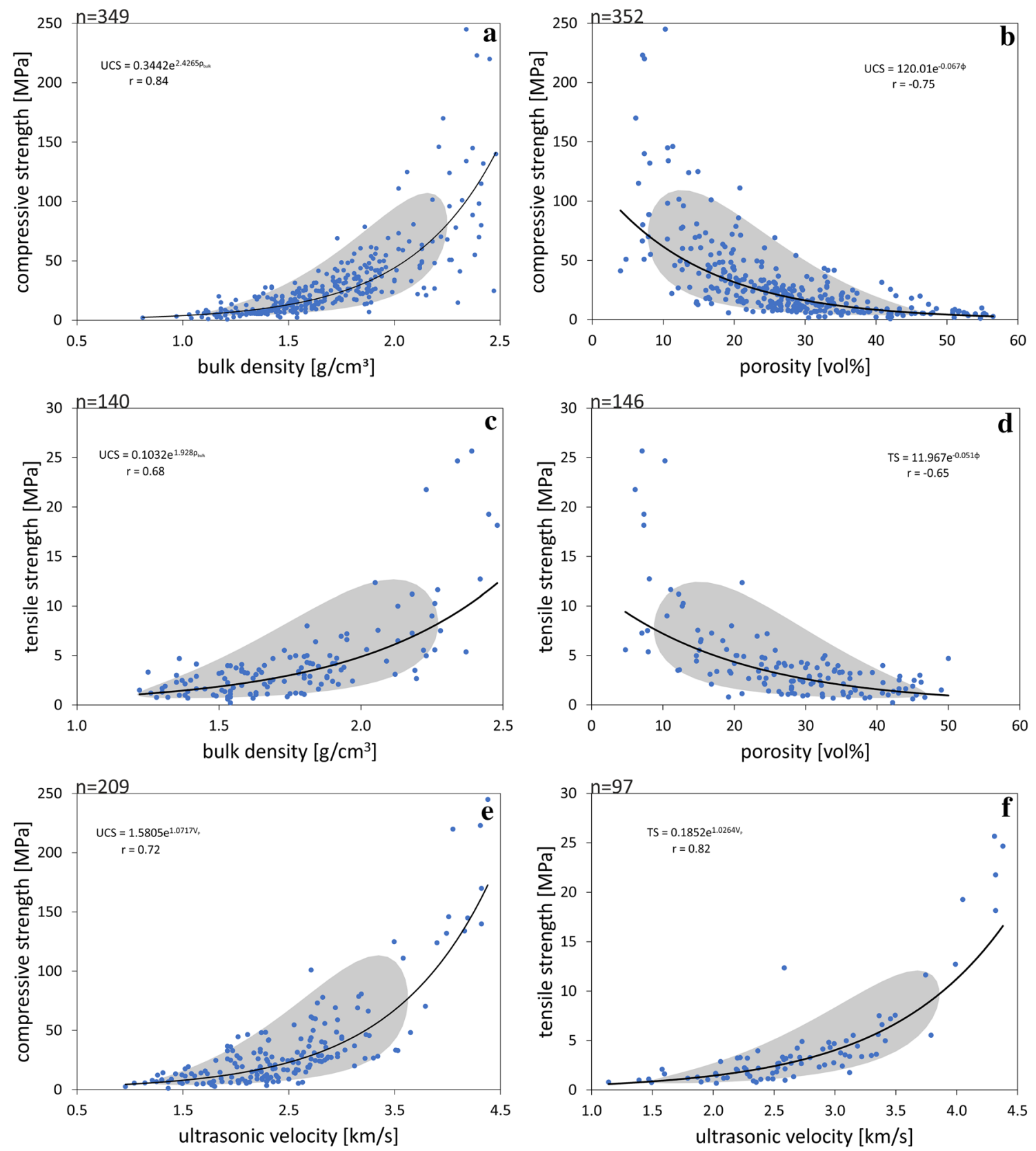

Fig. 10 Regression analysis of different rock properties with trendlines and $r$ values. The grey ellipses predict an $80 \%$ probability of the data. Data taken from references in Table 6 (data of this study included). $n=$ number of data pairs

Regarding their expansional behavior, tuffs with smaller pore radii tend to show higher hydric expansion values $(n=86)$. The relation between hydric expansion and mean pore radius is described by a negative quadratic trend with a weak to moderate correlation of $r=-0.42$. A negative quadratic trend, with weak correlation $(r=-0.35)$, can be observed for the hydric expansion and the resistance against salt weathering $(n=59)$. Increasing hydric expansion is consequently related to a lower mean pore radius and lower resistance to salt weathering (Fig. 11). The relation between the cation exchange capacity (CEC) and the hydric expansion of 53 data pairs is described by a moderate correlation coefficient $(r=0.53)$, but the data points are widely scattered and no clear trend is observable (Fig. 12). The CEC is a proxy for swellable clay minerals (Dohrmann and Kaufhold 2010); accordingly, their effect on moisture changes and their role in the tuffs studied is not as clear as expected. On the other hand, 5 of the 15 samples studied contain zeolites that do not show a significant $\mathrm{CEC}$ when measured using $\mathrm{Cu}$-trien, but may react significantly upon moisture changes, which may explain the 

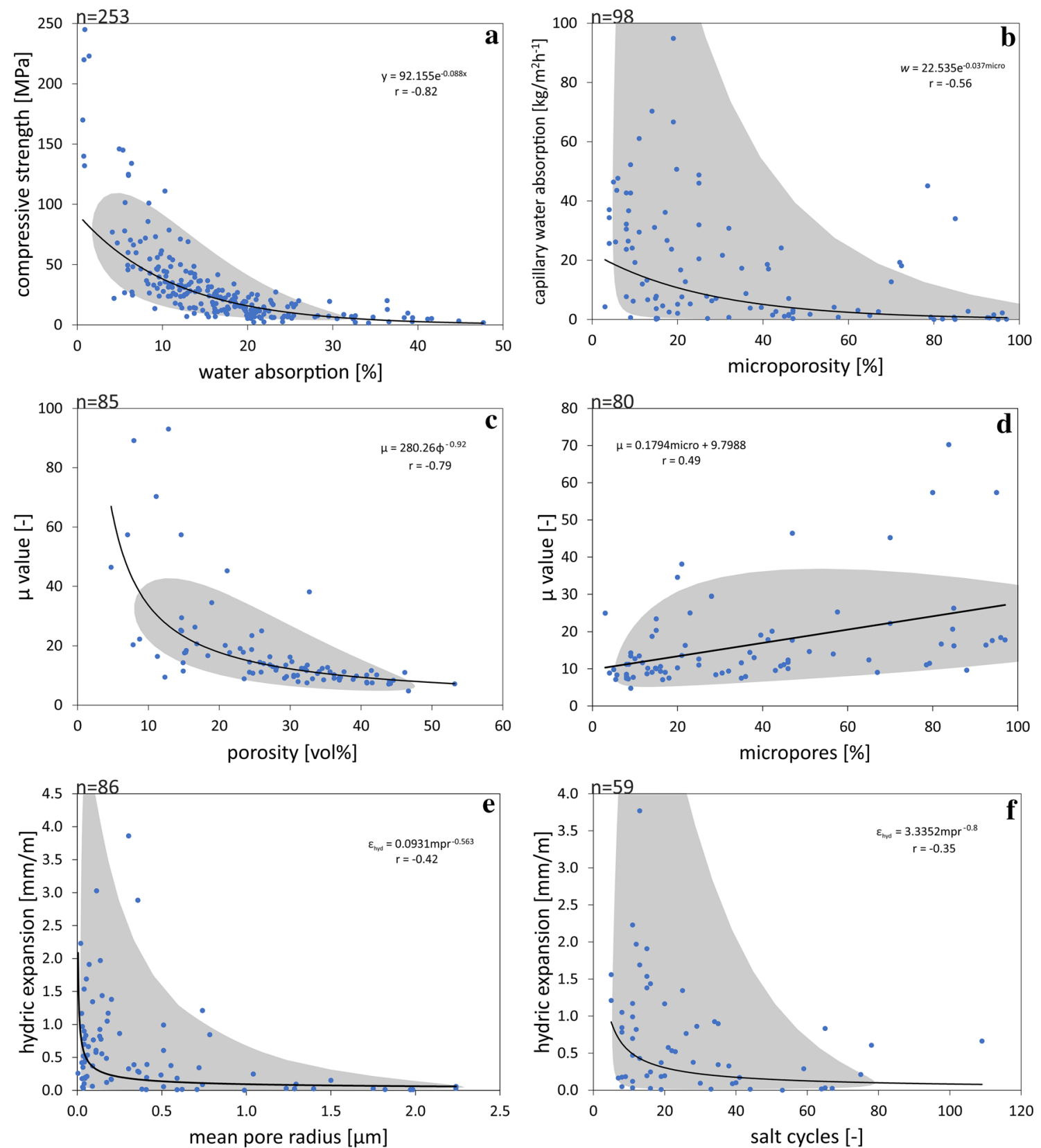

Fig. 11 Regression analysis of different rock properties with trendlines and $r$ values. The grey ellipses predict an $80 \%$ probability of the data. Data taken from references in Table 6 (data of this study included). $n=$ number of data pairs

poor correlation. It should be noted, however, that many tuffs with very low CEC tend to show hardly any expansion. Some even show contractional behavior (Fig. 12).

\section{Material behavior of crystal, vitric, lithic tuffs, and influence of the pore radius}

As the classification of tuffs after the recommended system of the IUGS (Schmid 1981) is usually not a part of most investigations, scientific data on this information are scarce, if not absent, in the literature. This, in part, also applies for the characterization of the pore size distributions, since their analysis is associated with increased costs and access to analytical tools. This section, however, should demonstrate the potential that resides in these classification tools. For this purpose, the 15 investigated tuffs of this study plotted in Figs. 13 and 14, were colored according to their classification after the main type of pyroclastic content (Schmid 1981) on one hand, and on the other after their pore radii distribution type (Ruedrich and Siegesmund 2006). 
Fig. 12 Relationship between the cation exchange capacity (CEC) and the hydric expansion of tuffs $(n=53)$ with trendline and $r$ value. Despite the moderate correlation coefficient, no clear trend is observable

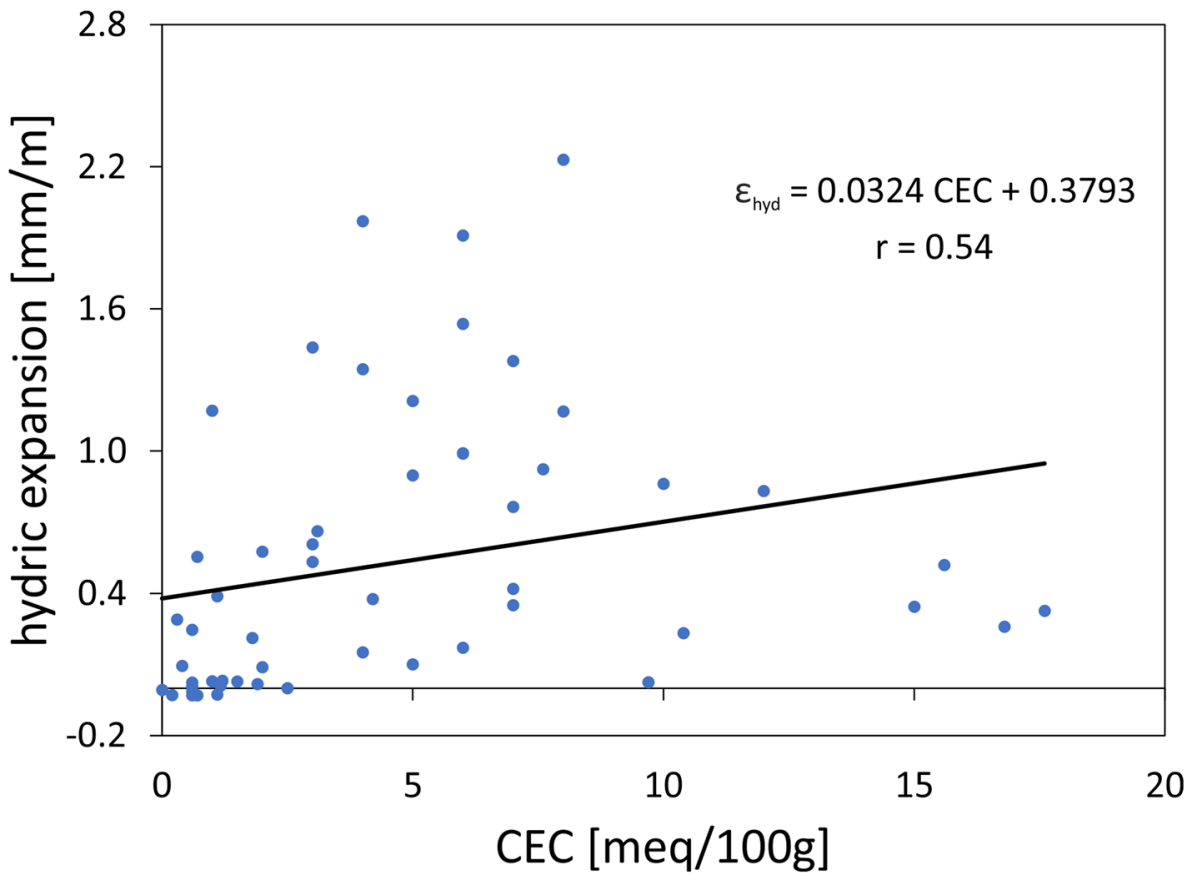

Several authors found strong relationships between the porosity and water absorption with the UCS for various clay bearing tuffs (e.g., Erguler and Ulusay 2009; Teymen 2018), which can be confirmed by this work (Figs. 10, 11). Furthermore, significant differences in the strength parameters can be observed when looking at the different types of tuff of this investigation. In Fig. 13, the relationship of the porosity and hydric expansion with the UCS and the reduction of UCS due to moisture saturation are displayed. The nature of the relationship between porosity and UCS was already described above as exponential (see Fig. 10). However, the onset of the exponential growth is mainly observed for tuffs with porosities $<10 \%$. As the 15 selected tuffs of this study do not obtain porosity values $<14.9 \%$, the relationship of the parameters in Fig. 10 would be rather described as linear in the investigated range (compare Fig. 13). This demonstrates the critical importance of comprehensive datasets when determining estimators, since the smaller data set produces entirely different predictions.

A strength reduction of tuffs due to water saturation is demonstrated by various studies (e.g., Çelik and Ergül 2015; Erguler and Ulusay 2009; Hashiba and Fukui 2015; Kleb and Vásárhelyi 2003; Masuda 2001; Okubo et al. 1992; Török et al. 2004; Vásárhelyi 2002; Wedekind et al. 2013; Yasar 2020). Yasar (2020) reported that already low amounts of moisture content, such as $0.2 \mathrm{wt} \%$, can lead to serious strength reduction. An overall observation in Fig. 13 is that tuffs with lower porosity usually show higher UCS, but also stronger UCS reduction due to water saturation. A more detailed examination identifies the differential material behavior by certain types of tuff, which was already indicated by the univariate analysis above. A grouping of tuffs above and below $30 \mathrm{vol} \%$ porosity seems possible (supporting the findings of Pötzl et al. 2018b), since vitric tuffs (>30 vol\% porosity) regularly show lower UCS and strength reduction than crystal tuffs ( $<30 \mathrm{vol} \%$ porosity). Because unimodal equal pore radii distribution is only represented by vitric tuffs of this study and unimodal unequal distribution mainly by crystal tuffs, a grouping by these two pore radii types seems also possible. Thus, unimodal equal pore distribution types display high porosity tuffs with lower UCS and accordingly lower UCS reduction than the unimodal unequal types, which show lower porosities and increased UCS, as well as higher UCS reduction due to water saturation. Bimodal pore radii types, however, are scattered over the whole range of porosities and strength values and do not seem to be suitable for a further differentiation of tuff characteristics. The classification of tuffs according to the type of pyroclasts (Schmid 1981) and the pore radii distribution type (Ruedrich and Siegesmund 2006) may only be seen as a potential proxy for a fast estimation of rock strength, and at this point, their utility for this purpose is surely lacking validation from comprehensive data.

Looking at the relationship between hydric expansion and UCS reduction, it becomes apparent that with increasing hydric expansion, the compressive strength decreases (Fig. 13). Therefore, vitric tuffs with typical low expansion values experience less strength reduction than crystal and lithic tuffs, which typically show increased hydric expansion (Fig. 13). López-Doncel et al. (2018) report similar behavior but with the thermal expansion of tuffs. When classified according to the pore radii distribution type, only the 

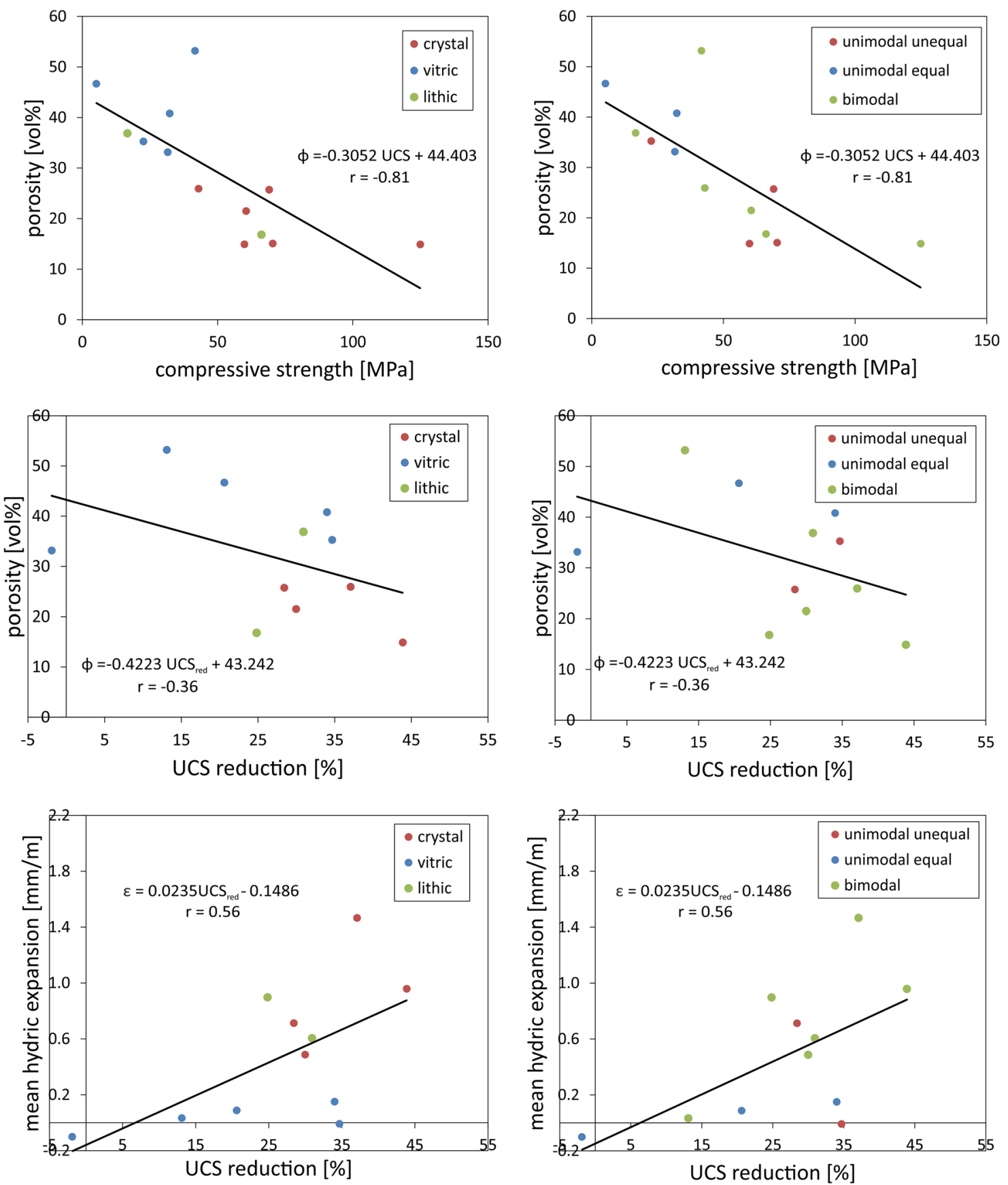

Fig. 13 Relationship between different rock properties with regard to their pyroclastic content and pore radii distribution type

unimodal equal type shows similarities with the behavior of the vitric tuffs. The only clear observation regarding unimodal unequal pore radii types is a typical high strength reduction. Bimodal types again scatter over the whole range of expansion values and UCS reduction and do not seem suitable for estimating a distinct behavior of the material.

The reduced strength connected to increased expansional behavior of certain tuff groups can also be transferred to their salt crystallization resistance. Low expanding vitric tuffs show higher resistance to salt weathering, unlike the higher expanding crystal tuffs, which show accordingly lower resistance (Fig. 14). A grouping after pore radii distribution type is again only suitable to a limited extent. As observed above, unimodal equal types coincide with the behavior of vitric type tuffs. Unimodal unequal types, with typical low to intermediate hydric expansion, show moderate resistance to salt weathering, while bimodal types show wide scattering. The lowest resistance to salt weathering in this study is shown by tuffs 

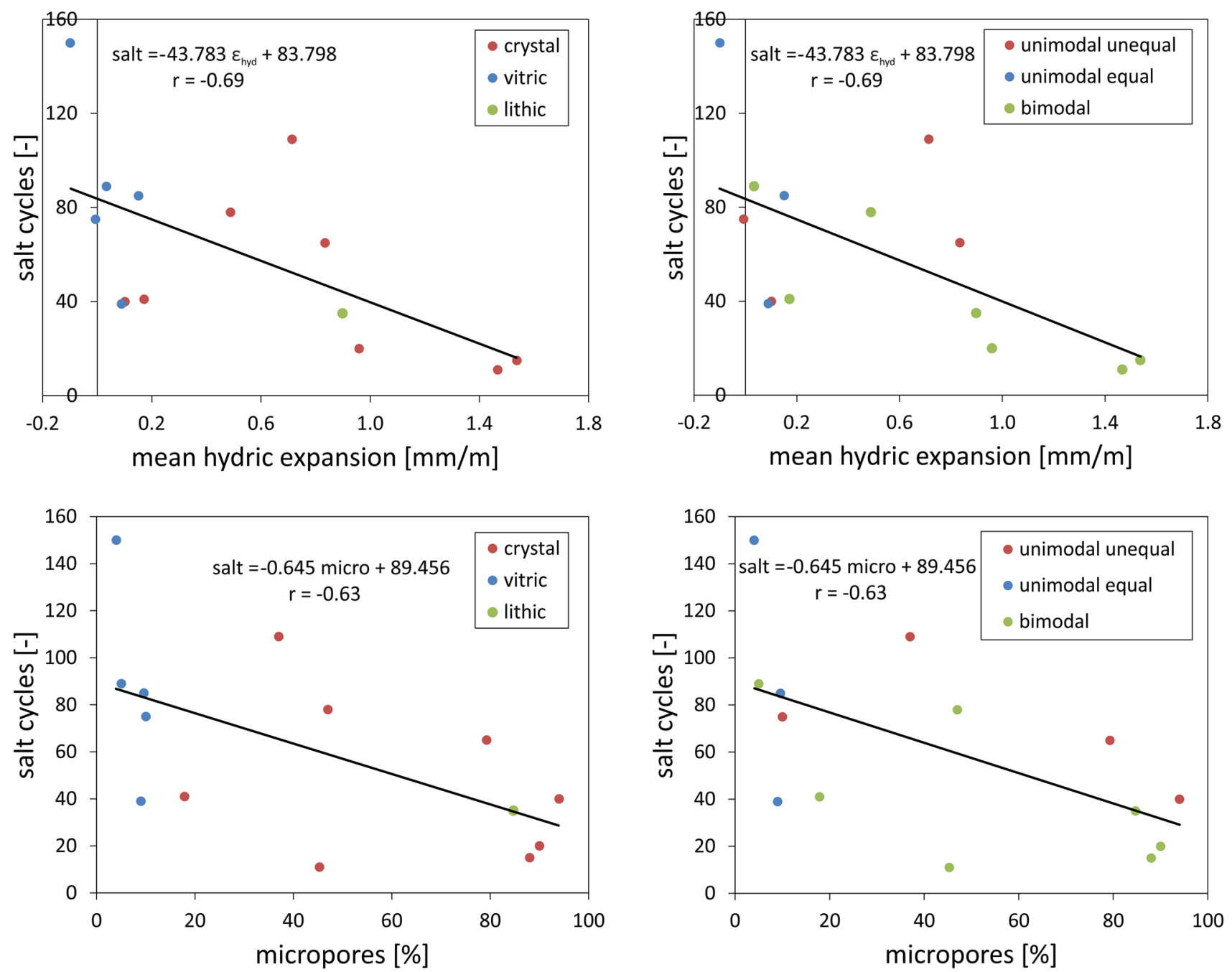

Fig. 14 Relationship between different rock properties with regard to their pyroclastic content and pore radii distribution type

of the bimodal type. These results confirm the observations in recent studies, where unimodal unequal and bimodal type tuffs with high fractions of micropores generally show higher susceptibility to salt crystallization (Çelik and Sert 2020; Germinario and Török 2019; López-Doncel et al. 2016; Pötzl et al. 2018b; Yu and Oguchi 2010). It is widely accepted that the generation of high crystallization pressures is facilitated by micropores (e.g., Fitzner and Snethlage 1982; Ruedrich et al. 2005; Scherer 1999; Steiger 2005a, b; Wellman and Wilson 1965). However, it should be noted that various authors define different sizes of micropores that facilitate the deterioration due to salt crystallization. Frequent sizes found in the literature range between $<0.05 \mu \mathrm{m}$ and $10 \mu \mathrm{m}$ (Benavente 2011; Steiger 2005b). To sum up, the pore size distribution may prove useful as an estimator of the salt weathering resistance of tuffs, as does the distinction between crystal and vitric type tuff, since the crystal type tuff usually shows lower durability (Fig. 14).

\section{Summary and conclusions}

The goal of this study was to identify key parameters that may be useful in the estimation of the strength and durability of tuffs by analyzing a dataset of more than 500 samples from the literature. Fifteen selected tuffs were investigated in more detail, to extrapolate to the very comprehensive, but less detailed dataset from the literature and achieve larger representability. Tuffs demonstrate to bear great mineralogical and fabric heterogeneity, and along with this heterogeneity, they show a wide range of technical parameters and responses to weathering. Especially, the porosity, water absorption, and hydric expansion can exceed values multiple times higher than other rock types (compare Siegesmund and Dürrast 2011). Although the analyses in this study are accompanied by a partly wide scattering of data, some strong correlations can be observed: 
Table 5 Some key differences of crystal and vitric tuffs observed on the set of 15 representative tuffs of this study

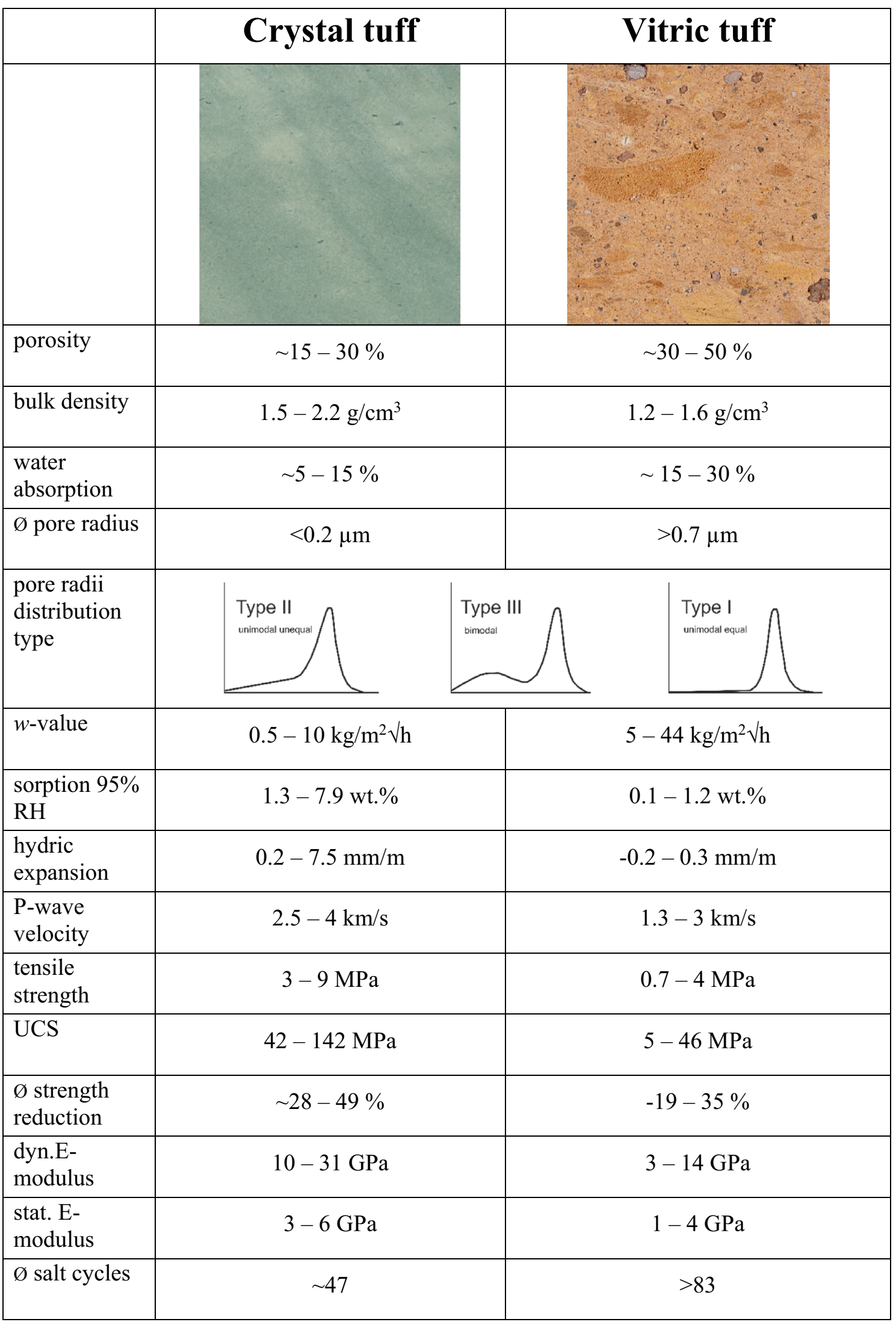

UCS uniaxial compressive strength, $w$ value capillary water absorption 
- Both porosity and bulk density are strongly related to the uniaxial compressive strength (UCS) and tensile strength (TS), and are therefore reliable estimators to predict the strength and durability of tuffs (UCS reduction).

- Both porosity and bulk density have a strong relation to the ultrasonic velocity, which in turn shows to be a good estimator for the strength of tuffs. This observation is not trivial, since tuffs can incorporate huge amounts of pumice clasts and lithics, that may considerably influence the propagation of the P-wave, e.g., due to increasing the pore space. Therefore, an ultrasonic testing device can help for a fast and non-destructive assessment of the materials' quality parameters, like it is reliably done for more homogenous natural stones and concrete (Sharma and Singh 2008).

- The hydric expansion is connected to both strength reduction and salt weathering. The higher the hydric expansion, the lower the tuffs durability. Similar to the observations of Wedekind et al. (2013) and contrary to other studies on clay bearing tuffs (Pötzl et al. 2018b) or sandstones (Ruedrich et al. 2011), the tuffs of this study do not show a clear correlation between the cation exchange capacity (CEC) and the intensity of their moisture expansion. This is possibly because the samples partly contain zeolites that may increase the CEC, but not actively contribute to the moisture expansion.

- The pore size distribution, categorized in one of the three pore radii types suggested by Ruedrich and Siegesmund (2006) (type I = unimodal equal, type II = unimodal unequal, and type III = bimodal), showed to be helpful in estimating general trends of material behavior. In doing so, unimodal unequal pore radii types are associated with crystal tuffs and unimodal equal pore radii types are associated with vitric tuffs. Tuffs with bimodal pore radii distribution turned out to be the most unpredictable in terms of their durability and their pore radii distribution alone may not give meaningful prognosis.

- Crystal and vitric tuffs show strongly differential characteristics in their technical parameters and durability, and are potentially useful for their estimation. Some key observations regarding crystal and vitric tuffs are: (1) Vitric tuffs are described by high porosity, with usually large mean pore radii and high water absorption. Their water vapor diffusion resistance, hygroscopic water sorption, and hydric expansion are generally low. The influence of water on their strength properties is considerably low and they show typically high resistance to salt weathering. (2) Crystal tuffs show typically lower porosity, with small mean pore radii and low to moderate water absorption. They often contain high amounts of swelling clays and zeolites that are connected to an increasing hydric expansion and hygroscopic water sorption, as well as a high resistance to water vapor diffusion.
Crystal tuffs show the highest strength values, but also the strongest decrease in strength due to water saturation. Their resistance to salt weathering is typically lower. In the practical applicability, the initial categorization of crystal and vitric tuffs after the classification system of Schmid (1981) may therefore help to give a broad picture of the expected material parameters (see Table 5). These observations need validation in future studies, as the literature does not provide sufficient constraints.

The basic relationships between the individual rock parameters found in this study confirm the results of previous studies on other rock types (Siegesmund and Dürrast 2011). They also confirm many findings of case studies on tuffs with relatively small datasets mentioned in the introduction. The comprehensive dataset of this study, however, does finally allow for more general statements, as this study provides the highest representability of tuffs so far.

Based on the results of this comprehensive dataset, it becomes apparent that the suitability of tuff as building stone also highly depends on the environmental (climate, exposure) conditions. As an example: tuffs with high potential for water absorption and retention in combination with considerable amounts of swelling clays (in this study often represented by crystal tuffs) should consequently not be applied in climatic zones with increased relative humidity or in areas that experience many wet-dry cycles, as they show a reduced resistance to hydric expansion processes and salt weathering. In dry environments, they may, however, be a suitable building material, since they typically possess increased strength values. Tuffs with predominantly large pore radii, low water vapor diffusion resistance, and a lack of swelling clays (in this study often represented by vitric tuffs) may absorb more water, but since this water is not retained for long and does not induce expansion processes or a high reduction of strength, they may be a more suitable type of tuff for humid environments. The application of volcanic tuffs in the base area of a building that is in contact with the ground moisture should be reconsidered, since the majority of tuffs show increased potential of capillary water uptake into the rising walls (Fig. 7). Many deterioration patterns in Armenian and Mexican tuff facades are associated with this high capillarity (Fig. 1). The application of a less porous and capillary active material in the base area, such as basalt, may significantly reduce/inhibit the water uptake and distribution of ground moisture.

\section{Appendix}

See Table 6. 
Table 6 Literature used for the compilation of the tuff database

References

Akın et al. (2017), Auras et al. (2000), Aydan and Ulusay (2003), Barahim et al. (2017), Barbero-Barrera et al. (2019), Beyhan et al. (2018),

Bianchetti et al. (1990), Binal (2009), Bozdağ et al. (2016), Bozdağ and Ince (2018), Bullmann (2001), Calcaterra et al. (2000, 2004, 2005), Çelik et al. (2014), Çelik and Aygün (2019), Çelik and Çobanoğlu (2019), Çelik and Ergül (2015, 2018), Çelik and Kaçmaz (2016), Çelik and Sert (2020), Chen and Yeung (2004), Colella et al. (2009, 2017), Columbu et al. (2014), Cueto Mendoza et al. (2018), Di Benedetto (2012), Dinçer et al. (2004), Dinçer and Bostanc1 (2019), Egloffstein (1998), Emir et al. (2011), Engidasew (2014), Ergenç et al. (2016), Fitzner (1985), Fratini et al. (1990), Germinario and Török (2019), Ghobadi et al. (2016), Gioncada et al. (2010), Hashemi et al. (2018), Heap et al. (2014), Hernández Gutiérrez (2014), İnce et al. (2019), İnce and Fener (2016), Jackson et al. (2005), Jamshidi et al. (2013), Kaljahi and Birami (2015), Katzschmann et al. (2006), Kılıç et al. (2019), Kılıç and Teymen (2008), Koralay et al. (2011), Koralay and Çelik (2019), Korat et al. (2015), Korkanç et al. (2015), Korkanç and Solak (2016), Kral (2014), Kück (2019), Kück et al. (2020a, b), La Russa et al. (2017), Lange and Steiner (1974), Langella et al. (2013), Laurenzi Tabasso et al. (1990), Leiser (2013), Li et al. (2020), Lindner (1994), López-Doncel et al. (2013, 2016, 2018), Lukaszewicz (1990), Marmoni et al. (2017a, b), Molina-Maldonado (2016), Möllenkamp (1996), Moon (1993), Nijland et al. (2010), Oguchi and Yuasa (2010), Öner et al. (2006), Özbek (2014), Özşen et al. (2017), Özvan et al. (2015), Papa (2011), Pola et al. (2012, 2014), Poschlod (1990), Pötzl (2015), Pötzl et al. (2018a, b), Rossi-Manaresi and TuccI (1990), Rucker et al. (2020), Sato and Hattanji (2018), Sert and Özkahraman (2016), Siedel (1995), Spizzichino et al. (2017), Sramek and Nishiura (1990), Steindlberger (2002, 2003, 2020), Stück (2006), Stück et al. (2008), Teipel (2020), Teymen (2018), Thomachot and Matsuoka (2007), Topal and Doyuran (1997), Topal and Sözmen (2001), Toprak and Arslanbaba (2016), Török et al. (2004, 2007, 2016), Türkdönmez and Bozcu (2012), Uğur and Toklu (2020), Ünal (2011), Useche (1990), van Hees et al. (2003), Velasco Sánchez (2013), Wedekind et al. (2011, 2013), Wendler et al. (1996), Wittenborn (2015), Yasar et al. (2009), Yavuz et al. (2015), Yüksek (2019), Yüksek and Demirci (2010)

Acknowledgements We are grateful to S. Rucker, A. Kück, K. Wemmer, K. Ufer, N. Schleuning, A. Marx, and M. Sitnikova for their laboratory support and help with the mineral analyses. We thank M. Hueck and J. Menningen for many helpful comments and V. Safaryan for the help with the sampling and sample transfer to Germany. This work was supported by the German Research Foundation (Si-438/52-1) and the Volkswagen Foundation (AZ93919). C. Pötzl gratefully acknowledges the financial support by the German Federal Environmental Foundation (AZ20017/481), the German Academic Exchange Service (ID 57212311) and the Georg-August-University School of Science (RTG2019).

Author contributions CP: conceptualization, analysis, investigation, writing, editing, and funding acquisition. SS: conceptualization, editing, supervision, project administration, and funding acquisition. RLD: writing, editing, and investigation. RD: analysis and editing.

Funding Open Access funding enabled and organized by Projekt DEAL. This work was supported by the German Research Foundation (Si-438/52-1) and the Volkswagen Foundation (AZ93919). C. Pötzl gratefully acknowledges the financial support by the German Federal Environmental Foundation (AZ20017/481), the German Academic Exchange Service (ID 57212311), and the Georg-August-University School of Science (RTG2019).

Data availability The data of the current study are available from the corresponding author on reasonable request.

\section{Declarations}

Conflict of interest The authors declare that there are no conflict of interest.

Ethical approval The authors declare that all principles of ethical and professional conduct have been followed.

Consent to participate All authors agreed to participate.
Consent for publication All author consent for publication.

Open Access This article is licensed under a Creative Commons Attribution 4.0 International License, which permits use, sharing, adaptation, distribution and reproduction in any medium or format, as long as you give appropriate credit to the original author(s) and the source, provide a link to the Creative Commons licence, and indicate if changes were made. The images or other third party material in this article are included in the article's Creative Commons licence, unless indicated otherwise in a credit line to the material. If material is not included in the article's Creative Commons licence and your intended use is not permitted by statutory regulation or exceeds the permitted use, you will need to obtain permission directly from the copyright holder. To view a copy of this licence, visit http://creativecommons.org/licenses/by/4.0/.

\section{References}

Akın M, Özvan A, Dinçer İ, Topal T (2017) Evaluation of the physicomechanical parameters affecting the deterioration rate of Ahlat ignimbrites (Bitlis, Turkey). Environ Earth Sci 76:827

Auras M, Steindlberger E (2005) Verwitterung und Festigung vulkanischer Tuffe. In: Zeitschrift der Deutschen Gesellschaft für Geowissenschaften, pp 167-175

Auras M, Egloffstein P, Steindlberger E (2000) Vulkanische Tuffsteine-Entstehung, Verwitterung, Konservierung. In: IFSBericht, Mainz, vol 10, pp 35-52

Aydan Ö, Ulusay R (2003) Geotechnical and geoenvironmental characteristics of man-made underground structures in Cappadocia, Turkey. Eng Geol 69:245-272

Barahim AA, Al-Akhaly IA, Is' haq RS (2017) Engineering properties of volcanic tuff from the western part of Yemen. Sultan Qaboos Univ J Sci SQUJS 22:81-88

Barbero-Barrera MM, Flores-Medina N, Moreno-Fernández E (2019) Thermal, physical and mechanical characterization of volcanic tuff masonries for the restoration of historic buildings. Mater Constr. https://doi.org/10.3989/MC.2019.12917 
Benavente D (2011) Why pore size is important in the deterioration of porous stones used in the built heritage. Macla 15:41-42

Benavente D, del Cura MG, Fort R, Ordóñez S (2004) Durability estimation of porous building stones from pore structure and strength. Eng Geol 74:113-127

Beyhan S, Sensogut C, Özgür A, Yuvka S (2018) the effect of freezethaw cycles on physical-mechanical properties of tuff. In: Çınar Ö (ed) ICENS proceedings 2018

Bianchetti PL, Lombardi G, Marini S, Meucci C (1990) The volcanic rocks of the monuments of the Forum and Palatine (Rome): characterization, alterations, and results of chemical treatments. In: Charola AE (ed) Lavas and volcanic tuffs: proceedings of the international meeting, Easter Island, Chile, 25-31 Oct, 1990, ICCROM, Rome, pp 83-105

Binal A (2009) Prediction of mechanical properties of non-welded and moderately welded ignimbrite using physical properties, ultrasonic pulse velocity, and point load index tests. Q J Eng Geol Hydrogeol 42:107-122

Bodnár N, Kovács J, Török Á (2011) Multivariate analysis of Miocene sediments: Rákóczi Square, new metro station area, Budapest, Hungary. Cent Eur Geol 54:391-405

Bozdağ A, Ince I (2018) Predicting strength parameters of igneous rocks from slake durability index. Afyon Kocatepe Üniversitesi Fen Ve Mühendislik Bilimleri Dergisi 18:1102-1109

Bozdağ A, Bayram AF, İnce İ, Asan K (2016) The relationship between weathering and welding degree of pyroclastic rocks in the Kilistra ancient city, Konya (Central Anatolia, Turkey). J Afr Earth Sci 123:1-9

Bullmann B (2001) Vergleichende Untersuchungen unteschiedlicher Steinfestiger auf Kieselsäureesterbasis. Diplomarbeit, FH Wiesbaden

Büttgenbach T (1990) Statistische Untersuchungen der Geschwindigkeits-Dichte Relation in kristallinen Gesteinen auf der Basis einer Datenbank. na

Calcaterra D, Cappelletti P, Langella A, Morra V, Colella A, de Gennaro R (2000) The building stones of the ancient centre of Naples (Italy): Piperno from Campi Flegrei: a contribution to the knowledge of a long-time-used stone. J Cult Herit 1:415-427

Calcaterra D, Cappelletti P, Langella A, Colella A, de Gennaro M (2004) The ornamental stones of Caserta province: the Campanian Ignimbrite in the medieval architecture of Casertavecchia. J Cult Herit 5:137-148

Calcaterra D, Langella A, de Gennaro R, de'Gennaro M, Cappelletti $P$ (2005) Piperno from Campi Flegrei: a relevant stone in the historical and monumental heritage of Naples (Italy). Environ Geol 47:341-352

Çelik MY, Aygün A (2019) The effect of salt crystallization on degradation of volcanic building stones by sodium sulfates and sodium chlorides. Bull Eng Geol Environ 78:3509-3529

Çelik SB, Çobanoğlu İ (2019) Comparative investigation of Shore, Schmidt, and Leeb hardness tests in the characterization of rock materials. Environ Earth Sci 78:554

Çelik MY, Ergül A (2015) The influence of the water saturation on the strength of volcanic tuffs used as building stones. Environ Earth Sci 74:3223-3239

Çelik MY, Ergül A (2018) Pore characterization of volcanic tuffs used as building stone in Afyonkarahisar (Turkey). Politek Derg 21:101-112

Çelik MY, Kaçmaz AU (2016) The investigation of static and dynamic capillary by water absorption in porous building stones under normal and salty water conditions. Environ Earth Sci 75:307

Çelik MY, Sert M (2020) The role of different salt solutions and their concentration ratios in salt crystallization test on the durability of the Döğer tuff (Afyonkarahisar, Turkey) used as building stones of cultural heritages. Bull Eng Geol Environ. https://doi.org/10. 1007/s10064-020-01896-7
Çelik MY, Akbulut H, Ergül A (2014) Water absorption process effect on strength of Ayazini tuff, such as the uniaxial compressive strength (UCS), flexural strength and freeze and thaw effect. Environ Earth Sci 71:4247-4259

Chen TC, Yeung MN (2004) Effect of water saturation on deterioration of welded tuff due to freeze-thaw action. Cold Reg Sci Technol 38:127-136

Colella A, Calcaterra D, Cappelletti P, Langella A, Papa L, Gennaro M de (2009) I tufi zeolitizzati nell'architettura della Campania. In: Cuzzolin M (ed) Diagnostica per la tutela e la conservazione dei materiali nel costruito. Atti del Convegno Diacomast, Belvedere di S. Leucio (CE), 21-22 Febbraio 2008, vol 1, pp 327-341

Colella A, Di Benedetto C, Calcaterra D, Cappelletti P, D'Amore M, Di Martire D, Graziano SF, Papa L, de Gennaro M, Langella A (2017) The Neapolitan Yellow Tuff: an outstanding example of heterogeneity. Constr Build Mater 136:361-373

Columbu S, Gioncada A, Lezzerini M, Marchi M (2014) Hydric dilatation of ignimbritic stones used in the church of Santa Maria di Otti (Oschiri, northern Sardinia, Italy). Ital J Geosci 133:149-160

Cueto Mendoza N, Vieira De Sousa JF, Fernandes C, Benavente D, Urbani F, Meza R, Santos Perneta JP, García del Cura M (2018) Water transport in lapilli tuff from Madeira Iland, Portugal: implications on degradation mechanisms and durability. In: Atas do $16^{\circ}$ Congresso Nacional de Geotecnia

Davarpanah SM, Ván P, Vásárhelyi B (2020) Investigation of the relationship between dynamic and static deformation moduli of rocks. Geomech Geophys Geoenergy Georesources 6:1-14

de Pablo-Galán L (1986) Geochemical trends in the alteration of Miocene vitric tuffs to economic zeolite deposits, Oaxaca, Mexico. Appl Geochem 1:273-285

Di Benedetto C (2012) Evaluation of petrophysical parameters of the Neapolitan Yellow Tuff and the Vicenza Stone: experimental investigation on conservation of macroporous building stones. Rivista Plinius, vol 38

Dinçer İ, Bostancı M (2019) Capillary water absorption characteristics of some Cappadocian ignimbrites and the role of capillarity on their deterioration. Environ Earth Sci 78:7

Dinçer I, Acar A, Çobanoğlu I, Uras Y (2004) Correlation between Schmidt hardness, uniaxial compressive strength and Young's modulus for andesites, basalts and tuffs. Bull Eng Geol Environ 63:141-148

Dohrmann R, Kaufhold S (2009) Three new, quick CEC methods for determining the amounts of exchangeable calcium cations in calcareous clays. Clays Clay Miner 57:338-352

Dohrmann R, Kaufhold S (2010) Determination of exchangeable calcium of calcareous and gypsiferous bentonites. Clays Clay Miner 58:79-88

Egloffstein P (1998) Vulkanische Tuffsteine als Werksteine an historischen Bauwerken in Ungarn und Deutschland-Verwitterungsverhalten und Konservierungskonzepte. Sven von Loga, Köln, pp 1-154

Emir E, Konuk A, Daloğlu G (2011) Strength enhancement of Eskisehir tuff ashlars in Turkey. Constr Build Mater 25:3014-3019

Engidasew TA (2014) Engineering geological characterization of volcanic rocks of Ethiopian and Sardinian highlands to be used as construction materials. Dissertation, Università di Cagliari

Ergenç D, Saltık ENC, Topal T (2016) Antique stone quarries in Turkey: a case study on tuffs in the Temple of Apollon Smintheus. Geol Soc Lond Spec Publ 416:133-144

Erguler ZA, Ulusay R (2009) Water-induced variations in mechanical properties of clay-bearing rocks. Int J Rock Mech Min Sci 46:355-370

Fisher RV (1966) Rocks composed of volcanic fragments and their classification. Earth Sci Rev 1:287-298

Fisher RV, Schmincke H-U (2012) Pyroclastic rocks. Springer Science $\&$ Business Media, Berlin 
Fitzner B (1985) Bauforschung T2190/1. Ermittlung von Baustoffkennwerten von Tuffgesteinen und die Möglichkeiten zur Erhöhung der Dauerhaftigkeit von Tuffsteinmauerwerk - Teil 1. Fraunhofer IRB Verlag, Stuttgart

Fitzner B, Basten D (1994) Gesteinsporosität--Klassifizierung, meßtechnische Erfassung und Bewertung ihrer Verwitterungsrelevanz. In: Jahresberichte aus dem Forschungsprogramm Steinzerfall, Steinkonservierung, Band 4, 1992, pp 19-32

Fitzner B, Snethlage R (1982) Einfluss der porenradienverteilung auf das verwitter ungsverhalten ausgewaehlter sandsteine. Bautenschutz+ Bausanierung 1982, pp 97-103

Fratini C, Manganelli del Fa C, Pecchioni E, Scala A (1990) The sculptures in Bomarzo Park, Viterbo, Italy. In: Charola AE (ed) Lavas and volcanic tuffs: proceedings of the international meeting, Easter Island, Chile, 25-31 Oct, 1990, ICCROM, Rome, pp 129-141

Germinario L, Török Á (2019) Variability of technical properties and durability in volcanic tuffs from the same quarry region-examples from Northern Hungary. Eng Geol 262:105319

Germinario L, Siegesmund S, Maritan L, Mazzoli C (2017) Petrophysical and mechanical properties of Euganean trachyte and implications for dimension stone decay and durability performance. Environ Earth Sci 76:739

Ghobadi MH, Beydokhti AT, Nikudel AA, Karakus M (2016) The effect of freeze-thaw process on the physical and mechanical properties of tuff. Environ Earth Sci 75:846

Gioncada A, Gonzalez-Ferran O, Lezzerini M, Mazzuoli R, Bisson M, Rapu SA (2010) The volcanic rocks of Easter Island (Chile) and their use for the Moai sculptures. Eur J Mineral 22:855-867

Gioncada A, Leoni L, Lezzerini M, Miriello D (2011) Relationships between mineralogical and textural factors in respect to hydric dilatation of some sandstones and meta-sandstones from the Northern Apennine. Ital J Geosci 130:394-403

González J, Saldaña M, Arzúa J (2019) Analytical model for predicting the UCS from P-wave velocity, density, and porosity on saturated limestone. Appl Sci 9:5265

Hashemi M, Basmenj AK, Banikheir M (2018) Engineering geological and geoenvironmental evaluation of UNESCO World Heritage Site of Meymand rock-hewn village, Iran. Environ Earth Sci 77:3

Hashiba K, Fukui K (2015) Effect of water on the deformation and failure of rock in uniaxial tension. Rock Mech Rock Eng 48:1751-1761

Heap MJ, Baud P, Meredith PG, Vinciguerra S, Reuschlé T (2014) The permeability and elastic moduli of tuff from Campi Flegrei, Italy: implications for ground deformation modelling. Solid Earth 5:25-44

Heap MJ, Farquharson JI, Kushnir ARL, Lavallée Y, Baud P, Gilg HA, Reuschlé T (2018) The influence of water on the strength of Neapolitan Yellow Tuff, the most widely used building stone in Naples (Italy). Bull Volcanol 80:51. https://doi.org/10.1007/ s00445-018-1225-1

Hernández Gutiérrez LE (2014) Caracterización geomecánica de las rocas volcánicas de las Islas Canarias. Dissertation, Universidad de La Laguna

Hirschwald J (1912) Die Prüfung der natürlichen Bausteine auf ihre Wetterbeständigkeit. W. Ernst \& Sohn, Berlin

İnce İ, Fener M (2016) A prediction model for uniaxial compressive strength of deteriorated pyroclastic rocks due to freeze-thaw cycle. J Afr Earth Sci 120:134-140

İnce İ, Bozdağ A, Fener M, Kahraman S (2019) Estimation of uniaxial compressive strength of pyroclastic rocks (Cappadocia, Turkey) by gene expression programming. Arab J Geosci 12:756

Jackson MD, Marra F, Hay RL, Cawood C, Winkler EM (2005) The judicious selection and preservation of tuff and travertine building stone in ancient Rome. Archaeometry 47:485-510
Jamshidi A, Nikudel MR, Khamechiyan M (2013) Estimating the durability of building stones against Salt crystallization: considering the physical properties and strength characteristics. Geopersia 3:35-48

Jamshidi A, Zamanian H, Sahamieh RZ (2018) The effect of density and porosity on the correlation between uniaxial compressive strength and P-wave velocity. Rock Mech Rock Eng 51:1279-1286

Kaljahi EA, Birami FA (2015) Engineering geological properties of the pyroclastic cone-shaped rocky houses of Kandovan, Iran. Bull Eng Geol Environ 74:959-969. https://doi.org/10.1007/ s10064-014-0679-4

Kılıç A, Teymen A (2008) Determination of mechanical properties of rocks using simple methods. Bull Eng Geol Environ 67:237

Kılıç A, Teymen A, Özdemir O, Atiş CD (2019) Estimation of compressive strength of concrete using physico-mechanical properties of aggregate rock. Iran J Sci Technol Trans Civ Eng 43:171-178

Kleb B, Vásárhelyi B (2003) Test results and empirical formulas of rock mechanical parameters of rhyolitic tuff samples from Eger's cellars. Acta Geol Hung 46:301-312

Koralay T, Çelik SB (2019) Minero-petrographical, physical, and mechanical properties of moderately welded ignimbrite as a traditional building stone from Uşak Region (SW Turkey). Arab J Geosci 12:732

Koralay T, Özkul M, Kumsar H, Celik SB, Pektaş K (2011) The effect of welding degree on geotechnical properties of an ignimbrite flow unit: the Bitlis castle case (eastern Turkey). Environ Earth Sci 64:869-881

Korat L, Mirtič B, Mladenovič A, Pranjić AM, Kramar S (2015) Formulation and microstructural evaluation of tuff repair mortar. J Cult Herit 16:705-711

Korkanç M, Solak B (2016) Estimation of engineering properties of selected tuffs by using grain/matrix ratio. J Afr Earth Sci 120:160-172

Korkanç M, Tuğrul A, Savran A, Özgür FZ (2015) Structural-geological problems in Gümüşler archeological site and monastery. Environ Earth Sci 73:4525-4540

Kral A (2014) Tuffsteine in Querétaro-City (México): Schadensanalyse, Verwitterungsverhalten und gesteinstechnische Untersuchungen. Bachelorarbeit, Georg-August-Universität

Kück A (2019) Weathering behaviour and petrophysical properties of volcanic tuff as historical building stone in Oaxaca, Mexico. Masterarbeit, Georg-August-Universität

Kück A, Pötzl C, López-Doncel RA, Dohrmann R, Siegesmund S (2020a) Effects of zeolites and swellable clay minerals on water related properties and thermal dilatation in volcanic tuff rocks. In: Siegesmund S, Middendorf B (eds) Monument future: decay and conservation of stone, 1st edn. Mitteldeutscher Verlag, Halle

Kück A, Pötzl C, López-Doncel RA, Dohrmann R, Siegesmund S (2020b) Weathering behavior and petrophysical properties of the natural building stones used in the archeological site of Mitla and colonial buildings in Oaxaca, Mexico. In: Siegesmund S, Middendorf B (eds) Monument future: decay and conservation of stone, 1st edn. Mitteldeutscher Verlag, Halle

La Russa MF, Ruffolo SA, de Buergo MÁ, Ricca M, Belfiore CM, Pezzino A, Crisci GM (2017) The behaviour of consolidated Neapolitan yellow Tuff against salt weathering. Bull Eng Geol Environ 76:115-124

Lange P, Steiner W (1974) Der Rochlitzer Porphyrtuff und seine Anwendung im Bauwesen der DDR. Z Angew Geol 20:520-525

Langella A, Bish D, Calcaterra D, Cappelletti P, Cerri G, Colella A, de'Gennaro R, Papa L, Graziano S, Perrotta A, Scarpati C, de'Gennaro M (2013) L'Ignimbrite Campana (IC). In: de Gennaro M, Calcaterra D, Langella A (eds) Le Pietre Storiche della Campania-dall'oblio alla riscoperta. Luciano Editore 
Laurenzi Tabasso M, Am Mecchi, Santamaria U (1990) Interaction between volcanic tuffs and products used for consolidation and waterproofing treatment. In: Charola AE (ed) Lavas and volcanic tuffs: proceedings of the international meeting, Easter Island, Chile, 25-31 Oct, 1990, ICCROM, Rome, pp 245-267

Le Bas MJ, Le Maitre RW, Streckeisen A, Zanettin B (1986) A chemical classification of volcanic rocks based on the total alkali-silica diagram. J Petrol 27:745-750

Le Maitre RW, Bateman P, Dudek A, Keller J, Lameyre J, Le BASMJ, Sabine PA, Schmid R, Sorensen H, Streckeisen A (1989) A classification of igneous rocks and glossary of terms. Recommendations of the IUGS subcommission on the systematics of igneous rocks. Blackwell Scientific Publications, London

Le Maitre RW, Streckeisen A, Zanettin B, Le BASMJ, Bonin B, Bateman P (2002) Igneous rocks: a classification and glossary of terms: recommendations of the international union of geological sciences subcommission on the systematics of igneous rocks, 2nd edn. Cambridge University Press, Cambridge

Leiser T (2013) Verwitterungscharakteristik von Tuff-Werksteinen in San Miguel de Allende (Mexiko): Schadensanalyse und gesteinstechnische Eigenschaften. Masterarbeit, Georg-August-Universität

Li L, Tan Y, Huang B, Deng X (2020) Pore property as an indicator of macro-deterioration in slightly weathered tuffs. Eng Geol 267:105492

Lindner K (1994) Die Naturwerksteine des Landkreises Altenburg. Diplomarbeit, Bauhaus-Universität Weimar

Liu J-b, Zhang Z-j, Li B (2019) Microscopic \& macroscopic characterizations of Beijing marble as a building material for UNESCO heritage sites: new insights into physico-mechanical property estimation and weathering resistance. Constr Build Mater 225:510-525

López-Doncel R, Wedekind W, Dohrmann R, Siegesmund S (2013) Moisture expansion associated to secondary porosity: an example of the Loseros Tuff of Guanajuato, Mexico. Environ Earth Sci 69:1189-1201

López-Doncel R, Wedekind W, Leiser T, Molina-Maldonado S, Velasco-Sánchez A, Dohrmann R, Kral A, Wittenborn A, Aguillón-Robles A, Siegesmund S (2016) Salt bursting tests on volcanic tuff rocks from Mexico. Environ Earth Sci 75:212

López-Doncel R, Wedekind W, Aguillón-Robles A, Dohrmann R, Molina-Maldonado S, Leiser T, Wittenborn A, Siegesmund S (2018) Thermal expansion on volcanic tuff rocks used as building stones: examples from Mexico. Environ Earth Sci 77:338

Lubelli B, Nijland TG, Tolboom H-J (2018a) Moisture induced weathering of volcanic tuffstone. Constr Build Mater 187:1134-1146

Lubelli B, Cnudde V, Diaz-Goncalves T, Franzoni E, van Hees RPJ, Ioannou I, Menendez B, Nunes C, Siedel H, Stefanidou M (2018b) Towards a more effective and reliable salt crystallization test for porous building materials: State of the art. Mater Struct 51:55

Lukaszewicz JW (1990) The application of silicone products in the conservation of volcanic tuffs. In: Charola AE (ed) Lavas and volcanic tuffs: proceedings of the international meeting, Easter Island, Chile, 25-31 Oct, 1990, ICCROM, Rome, pp 191-202

Marmoni GM, Martino S, Heap MJ, Reuschlé T (2017a) Gravitational slope-deformation of a resurgent caldera: new insights from the mechanical behaviour of Mt. Nuovo tuffs (Ischia Island, Italy). J Volcanol Geotherm Res 345:1-20

Marmoni GM, Martino S, Heap MJ, Reuschlé T (2017b) Multiphysics laboratory tests for modelling gravity-driven instabilities at slope scale. Proc Eng 191:142-149

Martin RJ III, Price RH, Boyd PJ, Haupt RW (1992) Anisotropy of the Topopah Spring Member Tuff. Sandia Report SAND91-0894, Albuquerque, New Mexico
Masuda K (2001) Effects of water on rock strength in a brittle regime. J Struct Geol 23:1653-1657

Meier L, Kahr G (1999) Determination of the cation exchange capacity (CEC) of clay minerals using the complexes of copper (II) ion with triethylenetetramine and tetraethylenepentamine. Clays Clay Miner 47:386-388

Molina-Maldonado S (2016) Estudios geológicos, petrográficos, geoquímicos y geotécnicos en las rocas de construcción del centro histórico de Santiago de Querétaro y su comportamiento al intemperismo. Masterarbeit, Universidad Autonoma de San Luis Potosi

Möllenkamp E (1996) Möglichkeiten der Tuffsteinkonservierung: Die Portalfiguren des Kölner Rathauses. Kölner Beiträge zur Restaurierung und Konservierung von Kunst- und Kulturgut, vol 4. Anton Siegl GmbH Fachbuchhandlung, München

Moon VG (1993) Geotechnical characteristics of ignimbrite: a soft pyroclastic rock type. Eng Geol 35:33-48

Morales Demarco M, Jahns E, Rüdrich J, Oyhantcabal P, Siegesmund S (2007) The impact of partial water saturation on rock strength: an experimental study on sandstone. Z Dtsch Ges Geowiss 158:869-882

Mosch S, Siegesmund S (2007) Statistisches Verhalten petrophysikalischer und technischer Eigenschaften von Naturwerksteinen [Petrophysical and technical properties of dimensional stones: a statistical approach]. Z Dtsch Ges Geowiss 158:821-868

Nijland TG, van Hees RPJ, Bolondi L (2010) Evaluation of three Italian tuffs (Neapolitan Yellow Tuff, Tufo Romano and Tufo Etrusco) as compatible replacement stone for Römer tuff in Dutch built cultural heritage. Geol Soc Lond Spec Publ 333:119-127

Oguchi CT, Yuasa H (2010) Simultaneous wetting/drying, freeze/thaw and salt crystallization experiments of three types of Oya tuff. Geol Soc Lond Spec Publ 333:59-72

Okubo S, Nishimatsu Y, He C, Chu SY (1992) Loading rate dependency of uniaxial compressive strength of rock under water-saturated condition. Zairyo 41:403-409

Öner F, Türkmen S, Özbek A, Karakaya T (2006) Engineering properties of Hinıs ignimbrites and their usability as a building stone (Erzurum, Turkey). Environ Geol 50:275-284

Özbek A (2014) Investigation of the effects of wetting-drying and freezing-thawing cycles on some physical and mechanical properties of selected ignimbrites. Bull Eng Geol Environ 73:595-609

Özşen H, Bozdağ A, İnce İ (2017) Effect of salt crystallization on weathering of pyroclastic rocks from Cappadocia. Turk Arab J Geosci 10:258

Özvan A, Dinçer İ, Akın M, Oyan V, Tapan M (2015) Experimental studies on ignimbrite and the effect of lichens and capillarity on the deterioration of Seljuk Gravestones. Eng Geol 185:81-95

Papa L (2011) I Tufi vulcanici nel costruito storico: vulnerabilità e possibili trattamenti per la conservazione e il restauro. Dissertation, Università degli Studi di Sassari

Pappalardo G, Punturo R, Mineo S, Contrafatto L (2017) The role of porosity on the engineering geological properties of 1669 lavas from Mount Etna. Eng Geol 221:16-28

Peschel A (1983) Natursteine. VEB Deutscher Verlag für Grundstoffindustrie, Leipzig

Pola A, Crosta G, Fusi N, Barberini V, Norini G (2012) Influence of alteration on physical properties of volcanic rocks. Tectonophysics 566:67-86

Pola A, Crosta GB, Fusi N, Castellanza R (2014) General characterization of the mechanical behaviour of different volcanic rocks with respect to alteration. Eng Geol 169:1-13

Poschlod K (1990) Das Wasser im Porenraum kristalliner Naturwerksteine und sein Einfluss auf die Verwitterung. Münchener Geowiss Abh Reihe B, Allgemeine und angewandte Geologie 7:1-62

Pötzl C (2015) Las Casas Tapadas de Plazuelas - Bauschäden, Verwitterungscharakteristik und gesteinstechnische Eigenschaften 
von Tuffsteinen in Guanajuato, Mexiko. Masterarbeit, Georg-August-Universität

Pötzl C (2020) Volcanic tuffs as natural building stones: mineralogy, technical properties, deterioration and conservation strategies. Dissertation, Georg-August-University

Pötzl C, Dohrmann R, Siegesmund S (2018a) Clay swelling mechanism in tuff stones: an example of the Hilbersdorf Tuff from Chemnitz, Germany. Environ Earth Sci 77:188

Pötzl C, Siegesmund S, Dohrmann R, Koning JM, Wedekind W (2018b) Deterioration of volcanic tuff rocks from Armenia: constraints on salt crystallization and hydric expansion. Environ Earth Sci 77:660

Rossi-Manaresi R, TuccI A (1990) Texture and mechanical disaggregation of tuffs from Italy and Ecuador. In: Charola AE (ed) Lavas and volcanic tuffs: proceedings of the international meeting, Easter Island, Chile, 25-31 October, 1990, ICCROM, Rome, p 73

Rucker S, Pötzl C, Wendler E, Dohrmann R, López-Doncel RA, Siegesmund S (2020) Improved consolidation of volcanic tuff rocks with TEOS. In: Siegesmund S, Middendorf B (eds) Monument future: decay and conservation of stone, 1st edn. Mitteldeutscher Verlag, Halle

Ruedrich J, Siegesmund S (2006) Fabric dependence of length change behaviour induced by ice crystallisation in the pore space of natural building stones. In: Heritage, weathering \& conservation: proceedings of the international conference on heritage, weathering and conservation, Taylor \& Francis, p 497

Ruedrich J, Kirchner D, Seidel M, Siegesmund S (2005) Beanspruchungen von Naturwerksteinen durch Salz-und Eiskristallisation im Porenraum sowie hygrische Dehnungsvorgänge. Z Dtsch Ges Geowiss 156:59-73

Ruedrich J, Bartelsen T, Dohrmann R, Siegesmund S (2011) Moisture expansion as a deterioration factor for sandstone used in buildings. Environ Earth Sci 63:1545-1564

Sato M, Hattanji T (2018) A laboratory experiment on salt weathering by humidity change: salt damage induced by deliquescence and hydration. Prog Earth Planet Sci 5:1-10

Scherer GW (1999) Crystallization in pores. Cem Concr Res 29:1347-1358

Schmid R (1981) Descriptive nomenclature and classification of pyroclastic deposits and fragments: recommendations of the IUGS Subcommission on the Systematics of Igneous Rocks. Geology 9:41-43

Sengun N, Demirdag S, Akbay D, Ugur I, Altindag R, Akbulut A (2014) Investigation of the relationships between capillary water absorption coefficients and other rock properties of some natural stones, V. In: Global stone congress, pp 22-25

Sert M, Özkahraman H (2016) The importance of welded tuff stones in construction industry according to their physico-mechanical properties. Harran Univ J Eng 1:8-18

Sharma PK, Singh TN (2008) A correlation between P-wave velocity, impact strength index, slake durability index and uniaxial compressive strength. Bull Eng Geol Environ 67:17-22

Siedel H (1995) Materialien der Kanzel und des Fundaments. In: Kiesewetter A, Siedel H, Stuhr M (eds) Die Tulpenkanzel im Dom zu Freiberg, vol 2, pp 68-74

Siedel H (2017) Verwendung, Eigenschaften und Verwitterung von Chemnitzer Zeisigwald-Tuff (,Hilbersdorfer Porphyrtuff“) als Bau- und Bildhauergestein. Veröff Mus Naturkunde Chemnitz 40:69-92

Siegesmund S, Dürrast H (2011) Physical and mechanical properties of rocks. In: Siegesmund S, Snethlage R (eds) Stone in architecture. Springer, Berlin, pp 97-225

Siegesmund S, Ullemeyer K, Weiss T, Tschegg EK (2000) Physical weathering of marbles caused by anisotropic thermal expansion. Int J Earth Sci 89:170-182
Snethlage R, Wendler E (1997) Moisture cycles and sandstone degradation. Environ Sci Res Rep ES 20:7-24

Sousa LMO (2014) Petrophysical properties and durability of granites employed as building stone: a comprehensive evaluation. Bull Eng Geol Environ 73:569-588

Sousa L, Siegesmund S, Wedekind W (2018) Salt weathering in granitoids: an overview on the controlling factors. Environ Earth Sci 77:502

Spizzichino D, Boldini D, Frodella W, Elashvili M, Margottini C (2017) Landslide risk analysis and mitigation for the ancient rock-cut city of Vardzia (Georgia). In: Proceedings of the 2017 IPL symposium UNESCO, Paris, France, pp 1-8

Sramek J, Nishiura T (1990) Assessment, by radioactive labelling, of the efficiency of conservation treatments applied to volcanic tuffs. In: Charola AE (ed) Lavas and volcanic tuffs: proceedings of the international meeting, Easter Island, Chile, 25-31 Oct, 1990, ICCROM, Rome, pp 205-216

Steiger M (2005a) Crystal growth in porous materials-I: the crystallization pressure of large crystals. J Cryst Growth 282:455-469

Steiger M (2005b) Crystal growth in porous materials-II: influence of crystal size on the crystallization pressure. J Cryst Growth 282:470-481

Steindlberger E (2002) Untersuchungen zum physiko-chemischen Verwitterungsverhalten hessischer Tuffsteine. Geologisch-Paläontologisches Inst. der Johann-Wolfgang-Goethe-Univ

Steindlberger E (2003) Vulkanische Gesteine aus Hessen und ihre Eigenschaften als Naturwerksteine. Teilw. zugl.: Frankfurt am Main, Univ., Diss., 2002 u.d.T.: Steindlberger, E.: Untersuchungen zum physiko-chemischen Verwitterungsverhalten hessischer Tuffsteine. Geologische Abhandlungen Hessen, vol 110. HLUG, Wiesbaden

Steindlberger E (2004) Volcanic tuffs from Hesse (Germany) and their weathering behaviour. Environ Geol 46:378-390

Steindlberger E (2007) Schalstein als Werkstein: Eigenschaften und Verwitterungsproblematik. In: IFS-Bericht, Institut für Steinkonservierung e.V. (ed) Die Konservierung des Heidenportals am Wetzlarer Dom. Neuartige Ansätze zur Erhaltung eines Problemgesteins, vol 27. IFS, Mainz, pp 9-22

Steindlberger E (2020) Konservierung hessischer Tuffe und Schalsteine unter Langzeitbeobachtung. In: Institut für Steinkonservierung e.V. (ed) Konservierungsstrategien für Rhyolithtuffmauerwerk, vol 60, Mainz, pp 51-70

Streckeisen A (1978) IUGS subcommission on the systematics of igneous rocks. Classification and nomenclature of volcanic rocks, lamprophyres, carbonatites and melilite rocks. recommendations and suggestions. Neues Jahrb Mineral Stuttg Abh 143:1-14

Stück H (2006) Materialeigenschaften und Verwitterungsprozesse bruchfrischer und konsolidierter Vulkanite. Diplomarbeit, Georg-August-Universität

Stück H, Forgó LZ, Rüdrich J, Siegesmund S, Török A (2008) The behaviour of consolidated volcanic tuffs: weathering mechanisms under simulated laboratory conditions. Environ Geol 56:699-713

Stück H, Koch R, Siegesmund S (2013) Petrographical and petrophysical properties of sandstones: statistical analysis as an approach to predict material behaviour and construction suitability. Environ Earth Sci 69:1299-1332

Teipel M (2020) Schadenskartierung und Charakterisierung armenischer Tuffsteine mit dem Ziel der Entwicklung kompatibler Steinergänzungsmassen für die Instandsetzung. Masterarbeit, Georg-August-Universität

Teymen A (2018) Prediction of basic mechanical properties of tuffs using physical and index tests. J Min Sci 54:721-733

Thomachot C, Matsuoka N (2007) Dilation of building materials submitted to frost action. Geol Soc Lond Spec Publ 271:167-177 
Topal T, Doyuran V (1997) Engineering geological properties and durability assessment of the Cappadocian tuff. Eng Geol 47:175-187

Topal T, Sözmen B (2001) Characteristics of the weathering zones developed within the tuffs of the Midas monument. Turk J Earth Sci 10:83-91

Toprak MU, Arslanbaba MA (2016) Possibility of using Kütahya Volcanic Tuff as building stone: microstructural evaluation and strength enhancement through heat treatment. Constr Build Mater 110:128-134

Török A, Gálos M, Kocsányi-Kopecskó K (2004) Experimental weathering of rhyolite tuff building stones and the effect of an organic polymer conserving agent. In: Stone decay: its causes and controls, pp 109-127

Török Á, Forgó LZ, Vogt T, Löbens S, Siegesmund S, Weiss T (2007) The influence of lithology and pore-size distribution on the durability of acid volcanic tuffs, Hungary. Geol Soc Lond Spec Publ 271:251-260

Török Á, Bögöly G, Czinder B, Görög P, Kleb B, Vásárhelyi B, Lovas T, Barsi Á, Molnár B, Koppányi Z, Somogyi JÁ, (, (2016) Terrestrial laser scanner aided survey and stability analyses of rhyolite tuff cliff faces with potential rock-fall hazards, an example from Hungary. In: Ulusay R, Aydan O, Gercek H, Hindistan MA, Tuncay E (eds) Rock mechanics and rock engineering: from the past to the future: Eurock 2016. Taylor and Francis Group, London, pp 877-881

Tukey JW (1977) Exploratory data analysis. In: Behavioral science: quantitative methods. Addison-Wesley Series

Türkdönmez O, Bozcu M (2012) The geological, petrographical and engineering properties of rhyolitic tuffs (Çan Stone) in Çan-Etili Area (Çanakkale), NW Turkey: their usage as building and covering stones. Open J Geol 2:25-33

Uğur İ, Toklu HÖ (2020) Effect of multi-cycle freeze-thaw tests on the physico-mechanical and thermal properties of some highly porous natural stones. Bull Eng Geol Environ 79:255-267

Ünal M (2011) The effect of salt crystallization on tuff used as building material. Eng Sci 6:41-49

Useche LA (1990) Studies for the consolidation of the facade of the church of Santo Domingo, Popayan, Colombia. In: Charola AE (ed) Lavas and volcanic tuffs: proceedings of the international meeting, Easter Island, Chile, 25-31 Oct, 1990, ICCROM, Rome, pp 165-172

van Hees RPJ, Brendle S, Nijland TG, de Haas G, Tolboom HJ (2003) Decay of Rhenish tuffs in Dutch monuments. Part 2: laboratory experiments as a basis for the choice of restoration stone. Heron 4(3):167-177

Vásárhelyi B (2002) Influence of the water saturation on the strength of volcanic tuffs. In: Dinis da Gama C, Ribeire e Sousa L (eds) Workshop on volcanic rocks. Eurock2002, Madeira, pp 89-96

Velasco Sánchez A (2013) Estudio petrografico, petrofisico y geoquimico de las rocas de construccion del de Templo de la Compañia de Jesús, Guanajuato, Mexico. Licenciatura, Universidad Autonoma de San Luis Potosi

Vernik L, Bruno M, Bovberg C (1993) Empirical relations between compressive strength and porosity of siliciclastic rocks. In: International journal of rock mechanics and mining sciences \& geomechanics abstracts, Elsevier, pp 677-680
Wedekind W (2016) Weathering and conservation of monuments constructed from tuff and sandstone in different environmental conditions. Georg-August-Universität Göttingen

Wedekind W, Ruedrich J, Siegesmund S (2011) Natural building stones of Mexico-Tenochtitlán: their use, weathering and rock properties at the Templo Mayor, Palace Heras Soto and the Metropolitan Cathedral. Environ Earth Sci 63:1787-1798

Wedekind W, López-Doncel R, Dohrmann R, Kocher M, Siegesmund S (2013) Weathering of volcanic tuff rocks caused by moisture expansion. Environ Earth Sci 69:1203-1224

Weiss T, Siegesmund S, Dt K, Sippel J (2004) Insolation weathering and hygric dilatation: two competitive factors in stone degradation. Environ Geol 46:402-413

Wellman HW, Wilson AT (1965) Salt weathering, a neglected geological erosive agent in coastal and arid environments. Nature 205:1097-1098

Wendler E (2007) Entwicklung von materialspezifischen Konservierungsstrategien zur Konsolidierung und Prophylaxe. In: IFS-Bericht, Institut für Steinkonservierung e.V. (ed) Die Konservierung des Heidenportals am Wetzlarer Dom. Neuartige Ansätze zur Erhaltung eines Problemgesteins, vol 27, IFS, Mainz, pp 69-76

Wendler E, Charola AE, Fitzner B (1996) Easter Island tuff: Laboratory studies for its consolidation. In: Riederer J (ed) Proceedings of the 8th international conference on the deterioration and conservation of stone, Berlin, pp 1159-1170

Wittenborn A (2015) Tuffverwitterung am Franziskaner Konvent in Zacatecas, Mexiko: Schadenskartierung und gesteinstechnische Charakterisierung der Verwitterungsphänomene. Bachelorarbeit, Georg-August-Universität

Xue Y, Kong F, Li S, Zhang L, Zhou B, Li G, Gong H (2020) Using indirect testing methods to quickly acquire the rock strength and rock mass classification in tunnel engineering. Int $\mathrm{J}$ Geomech 20:5020001

Yasar S (2020) Long term wetting characteristics and saturation induced strength reduction of some igneous rocks. Environ Earth Sci 79:1-12

Yasar E, Tolgay A, Teymen A (2009) Industrial usage of NevsehirKayseri (Turkey) tuff stone. World Appl Sci J 7:271-284

Yavuz AB, Akal C, Türk N, Çolak M, Tanyu BF (2015) Investigation of discrepancy between tuff used as building stones in historical and modern buildings in western Turkey. Constr Build Mater 93:439-448

Yu S, Oguchi CT (2010) Role of pore size distribution in salt uptake, damage, and predicting salt susceptibility of eight types of Japanese building stones. Eng Geol 3:226-236

Yüksek S (2019) Mechanical properties of some building stones from volcanic deposits of mount Erciyes (Turkey). Mater Constr 69:187

Yüksek S, Demirci A (2010) Geotechnical properties of volcanic materials of the Mount Erciyes. In: 3rd International workshop on volcanic rocks, rock mechanics, pp 99-105

Publisher's Note Springer Nature remains neutral with regard to jurisdictional claims in published maps and institutional affiliations. 